\title{
Assessing the dendroclimatic potential of Nothofagus betuloides (Magellan's beech) forests in the southernmost Chilean Patagonia
}

\author{
Mauricio Fuentes $^{1} \mathbb{D} \cdot$ Juan Carlos Aravena ${ }^{2} \cdot$ Andrea Seim $^{3} \cdot$ Hans W. Linderholm $^{1}$
}

Received: 30 November 2017 / Accepted: 15 December 2018 / Published online: 21 December 2018

(c) The Author(s) 2018

\begin{abstract}
Key message Tree growth of Nothofagus betuloides forests south of $50^{\circ} \mathrm{S}$ is affected by local temperature and precipitation together with large-scale high-latitude climate patterns, but also significant influences from the Tropical Pacific were found.

The characterization of past climate dynamics in southern South America is difficult due to the shortness of instrumental data. However, abundant forests in the southernmost part of the continent makes it an ideal place to assess the dendroclimatological potential for developing high-resolution climate proxy time series to extend the observations back in time. Whereas the majority of dendroclimatological studies have focused on latitudes north of $50^{\circ} \mathrm{S}$, we present six new Magellan's beech (Nothofagus betuloides (Mirb.) Oerst.) tree-ring width (TRW) chronologies, spanning between 202 and 500 years, developed from southernmost Patagonia $\left(>50^{\circ} \mathrm{S}\right)$, Chile. The climate signal in the trees was analyzed using local station data, regional sea surface temperature (SST) and large-scale atmospheric indices: the Southern Oscillation Index (SOI) and the southern annual mode (SAM). The correlations between individual site chronologies and observed summer temperatures and precipitation varied, reflecting diverse microsite conditions and local scale geographic patterns. An influence of southern Pacific SST was evident at two of the northern sites. Although the associations with SOI and SAM were weak, the influence of regional sea level pressure on tree growth in the region was evident.
\end{abstract}

Keywords Tree rings $\cdot$ Nothofagus betuloides $\cdot$ Climate signal $\cdot$ SAM $\cdot$ SOI $\cdot$ SST $\cdot$ SLP $\cdot$ South Pacific

\section{Introduction}

Few studies have analyzed the climatic influence on tree growth, and hence their dendroclimatological potential, in a regional context in southernmost South America. The

Communicated by Braeuning.

Electronic supplementary material The online version of this article (https://doi.org/10.1007/s00468-018-1801-1) contains supplementary material, which is available to authorized users.

Mauricio Fuentes

Mauricio.fuentes@gu.se

1 Regional Climate Group, Department of Earth Sciences, University of Gothenburg, Box 460, 40530 Göteborg, Sweden

2 Universidad de Magallanes, Punta Arenas, Chile

3 Chair of Forest Growth and Dendroecology, Institute of Forest Sciences, University of Freiburg, Freiburg, Germany remoteness of southernmost Patagonia and the inaccessibility of the archipelago of Tierra del Fuego make the few available datasets highly valuable (see Boninsegna et al. 2009). In this remote area, the shortness and scarceness of instrumental climate data, seldom exceeding 100 years, limits the understanding of past climate dynamics. Nevertheless, the effects of temperature and precipitation, together with large-scale atmospheric patterns, have been recorded in diverse paleoclimate archives, such as lake sediments (Moreno et al. 2014) and tree rings (Boninsegna et al. 2009). Specifically, tree-ring data have gained increasing attention due to their annual resolution and spatial availability, providing opportunities for reconstructions of different climate parameters back in time (Aravena et al. 2002; Villalba et al. 2003, 2012). Tree rings are, however, a biological proxy, implying that the climate information from different chronologies in the same area may vary according to site characteristics and microsite conditions (Fritts 1976; Boninsegna et al. 1989; Linderholm et al. 2015). When conducting dendroclimatological analysis in southernmost Patagonia and 
its archipelago, it is important to consider the uniqueness of the environment. Here, the heterogeneity of the geography is due to the topography, with mountains rising from sea level up to more than $2000 \mathrm{~m}$ a.s.l., interspersed with valleys and glaciers (Pisano 1977). This mosaic-like landscape must also be seen within a larger geographical context, which encompasses a permanent influence of the Southern Ocean, the westerly winds and a distinct precipitation gradient from west to east (Carrasco et al. 2002; Schneider et al. 2003; Garreaud et al. 2013). These factors determine the hydrological cycle and thus, affect various ecosystems in the region, and prompt site-specific responses of tree growth to local temperature and precipitation regimes (Boninsegna et al. 1989; Llancabure 2011; Lara et al. 2015; Soto-Rogel and Aravena 2017).

South of $45^{\circ} \mathrm{S}$, climate-growth responses have previously been studied using Nothofagus species (N. pumilio, N. antarctica and $N$. betuloides) (see, Villalba et al. 2003, Lara et al. 2005; Aravena et al. 2002; Boninsegna et al. 1989). Boninsegna et al. (1989) presented the very first dendroclimatological study of $N$. betuloides and $N$. pumilio south of the $50^{\circ} \mathrm{S}$ parallel in Tierra del Fuego. In their study, the authors presented the first 400-year long regional temperature reconstruction. They also noted varying climate signals in trees among the studied sites indicating a distinct variability in tree-growth sensitivity to climate in the region. Overall, few tree-ring chronologies have been developed from the southern Patagonian region. Aravena et al. (2002) demonstrated the temperature sensitivity of $N$. pumilio close to the tree line between 50 and $55^{\circ} \mathrm{S}$. Other studies have analyzed the temperature and precipitation signal in Nothofagus spp. on local as well as regional scales (Villalba et al. 1997, 2003; Llancabure 2011; Soto-Rogel and Aravena 2017). Moreover, Villalba et al. (1997) included Nothofagus spp. tree-ring data from southern Patagonia in a reconstruction of the sea level pressure (SLP) surrounding Antarctica, creating the so-called Summer Transpolar Index. This index describes the dominance of cyclonic (anticyclonic) activity and thus temperature variability in the Southern Hemisphere. Examining the latitudinal variation of temperature patterns along the southern Andes, Villalba et al. (2003) developed two temperature reconstructions from $N$. pumilio extending back to $1640 \mathrm{CE}$, one for the northern $\left(37-43^{\circ} \mathrm{S}\right)$ and one for the southern part $\left(>50^{\circ} \mathrm{S}\right)$. Reconstructed temperature variability for the north and south were linked to SST patterns in the Pacific and southern Atlantic Oceans, respectively, indicating different oceanic influences on temperatures from $37^{\circ} \mathrm{S}$ to $55^{\circ} \mathrm{S}$.

The El Niño Southern Oscillation (ENSO) is a phenomenon of coupled atmospheric and oceanic patterns. Treering studies of the impact of ENSO on local and regional climates have largely been restricted to northern latitudes (e.g., Le Quesne et al. 2006), likely due to the sensitivity to hydrological changes of trees growing in drier areas (Christie et al. 2009). Moreover, the influence of ENSO decreases at higher southern latitudes (Garreaud et al. 2009), although some influence on precipitation has been noted (Schneider and Gies 2004; Aravena and Luckman 2009). The southern annular mode (SAM) represents the mass exchange between the mid- and high-latitude bands in the southern hemisphere (Gong and Wang 1999; Marshall 2003; Garreaud et al. 2013, and references therein) and describes the latitudinal displacement of the main stream of the westerly flow, i.e., the path of the storm tracks (Jones 2012). The SAM has been shown to influence tree growth of different species throughout the southern hemisphere (Villalba et al. 2012).

The aim of this study was to investigate the climatic signal in six newly developed $N$. betuloides TRW chronologies from the southernmost forests in the world in Patagonia, South America. The climate-growth relationship was assessed using instrumental data (temperature and precipitation), atmospheric circulation indices such as the Southern Oscillation Index (SOI), the southern annular mode (SAM), sea surface temperature (SST) and SLP anomalies. The results are discussed regarding climate controls on tree growth in this unique and diverse region, and the potential for future tree-ring-based climate reconstructions.

\section{Materials and methods}

\section{Climate of the study area}

The climate in southwestern Patagonia, Chile, is characterized as hyper-humid and moderately cold, with a reduced seasonal cycle due to the oceanic influence and the dominant westerly winds (Miller 1976; Schneider and Gies 2004). Orographic effects causes one of the most extreme rainfall gradients in the world, ranging from annual sums of 2888-542 $\mathrm{mm} \mathrm{y}^{-1}(1971-2000)$ at Islotes Evangelistas $\left(52^{\circ} 40^{\prime} \mathrm{S}, 75^{\circ} 06^{\prime} \mathrm{W}\right)$ and Puerto Williams $\left(54^{\circ} 55^{\prime} \mathrm{S}\right.$, $\left.67^{\circ} 36^{\prime} \mathrm{W}\right)$, respectively. Maximum precipitation in the western areas ranges from 5000 to $10,000 \mathrm{~mm} \mathrm{year}^{-1}$ (Miller 1976; see also; Carrasco 2002; Aravena and Luckman 2009; Quintana and Aceituno 2012), with greater totals on elevations above $1500 \mathrm{~m}$ a.s.l. (Schneider et al. 2003; Villalba et al. 2003; Garreaud et al. 2013). Temperatures in southwestern Patagonia are relatively homogeneous: in Punta Arenas $\left(53^{\circ} 9^{\prime} \mathrm{S}, 70^{\circ} 55^{\prime} \mathrm{W}\right)$ winter (June through August) and summer (December through February) temperature means are $1.5^{\circ} \mathrm{C}$ and $10.1{ }^{\circ} \mathrm{C}$, respectively, with an annual mean of $6{ }^{\circ} \mathrm{C}$ (1971-2000). The variability of precipitation and temperature in southern Patagonia is largely depending on the westerly wind flow (Carrasco et al. 2002), which during the austral summer is organized into two bands centered at around $40^{\circ} \mathrm{S}$ and $60^{\circ} \mathrm{S}$, and is related to the exchange of 
atmospheric pressure described by the SAM. The westerly wind flow is positively correlated with precipitation throughout the year (Schneider et al. 2003), and negatively correlated with temperature during the summer season (Garreaud et al. 2013).

\section{Site characteristics}

Magellan's beech ( $N$. betuloides (Mirb.) Oerst.) is a broadleaved evergreen Nothofagaceae tree species that can reach up to $2 \mathrm{~m}$ in diameter and $30 \mathrm{~m}$ in height, and may reach ages of 600 years. It is distributed across Patagonia (south of $40^{\circ} \mathrm{S}$ ), growing in pure and mixed forests in association with $N$. pumilio or $N$. antarctica. Other accompanying tree species found in the southern archipelago are Tepualia stipularis and Drimys winterii. Magellan's beech grows on young soils, which have originated from volcanism and glaciofluvial processes. Most of the soils in the region are podsols and inceptisols (Gerding et al. 2002) and are characterized by low moisture and nutrient levels. $N$. betuloides is endemic to the sub-Antarctic forest region forming the southernmost forest in the world up to the $56^{\circ} \mathrm{S}$ parallel.

Six sites were sampled between 2011 and 2014 in the southern archipelago of Magallanes (Fig. 1). The westernmost site was Alejandro Valley (ALE; $125 \mathrm{~m}$ a.s.1., 534' $\mathrm{S}$, $72^{\circ} 29^{\prime} \mathrm{W}$ ) on Santa Inés Island (Fig. 1; Table 1), which is located in the western outlet of the Magellan Strait towards the Pacific Ocean. The remaining five sites were collected in southwestern Tierra del Fuego: two on the hillsides surrounding the lakes Lago Fagnano (DF2, 300-400 m a.s.l., $54^{\circ} 24^{\prime} \mathrm{S}, 68^{\circ} 42^{\prime} \mathrm{W}$ ), and Lago Despreciado, (DP, ca. $400 \mathrm{~m}$ a.s.l., $54^{\circ} 25^{\prime} \mathrm{S}, 68^{\circ} 49^{\prime} \mathrm{W}$ ), and one slightly north of these: site Ten (ST, $250-300 \mathrm{~m}$ a.s.1., $54^{\circ} 10^{\prime} \mathrm{S}, 68^{\circ} 47^{\prime} \mathrm{W}$ ). The two southernmost sites were Valle de los Divorcios (VD2; ca. $300 \mathrm{~m}$ a.s.1., $54^{\circ} 36^{\prime} \mathrm{S}, 69^{\circ} 03^{\prime} \mathrm{W}$ ) and Nueva Zelanda glacier valley (NZ, 10 to $80 \mathrm{~m}$ a.s.1., $54^{\circ} 42^{\prime} \mathrm{S}, 69^{\circ} 20^{\prime} \mathrm{W}$ ). Three of the sites (ALE, VD2 and NZ) were located close to fjords, while at DF2, DP and ST the trees grow at inland locations less exposed to winds. Also, ALE, NZ and VD2 were located closer to glaciers than the other sites.

At all sites, trees growing with obvious signals of disturbances such as avalanches or landslides were avoided. It is worth to mention that even-featured sites are almost impossible to find in the Archipelago of Tierra del Fuego due to the extreme differences in microsite conditions with respect to altitude, aspect, slope and exposure to wind, etc. Thus, at every site unique characteristics affect the tree growth. The general appearance of the trees sampled indicated some sort of environmental stress, visible, for example, in the low height of the trees, and often reduced crown diameters.

Core samples were extracted using Haglöf increment borers at ca. $1.3 \mathrm{~m}$ height from the root collar when possible. If applicable, cross sections were collected using a chainsaw at about $1.3 \mathrm{~m}$ from the root collar from dead trees. The
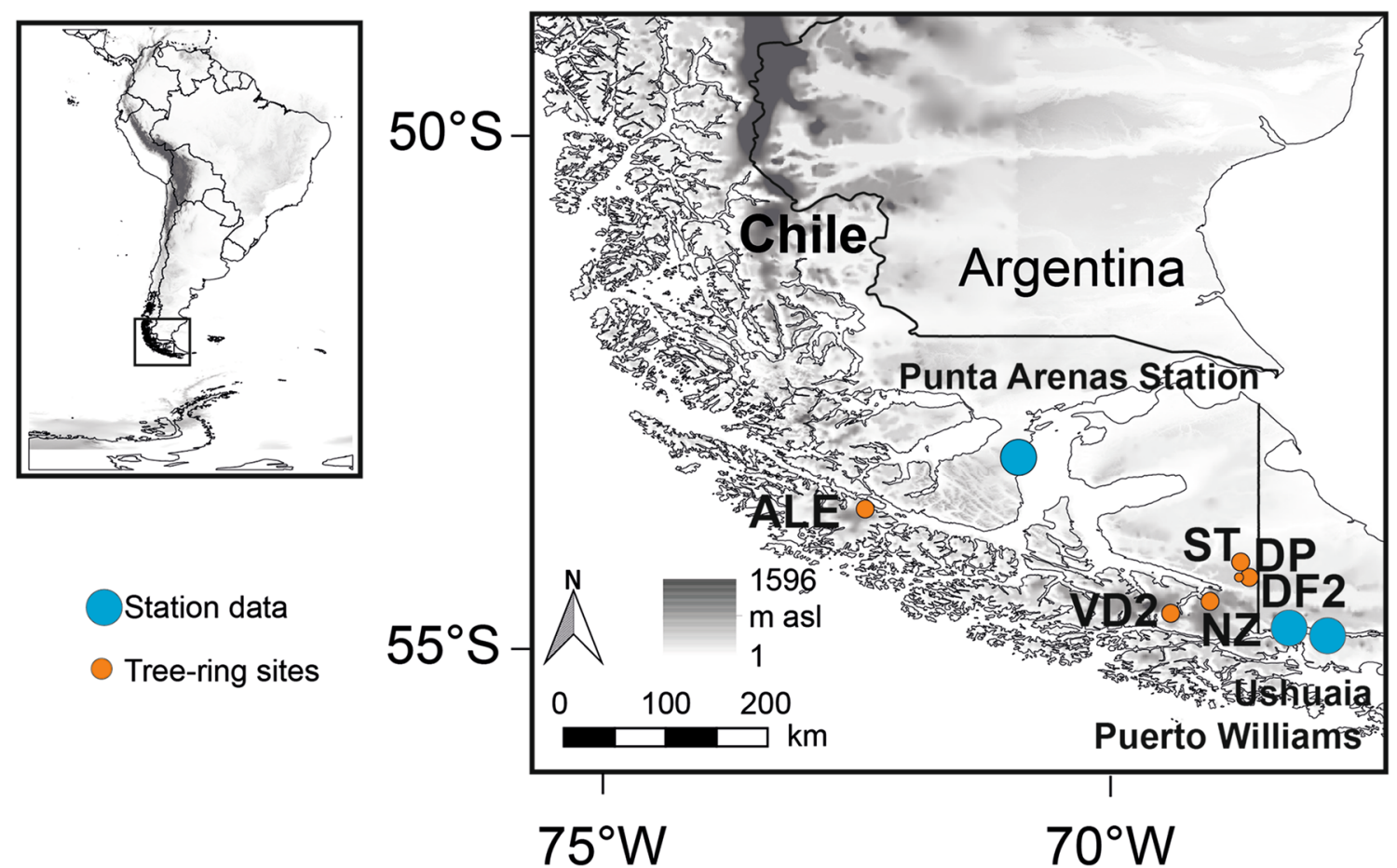

Fig. 1 Location of the sampling sites (orange dots) in Archipelago of Tierra del Fuego, southern Chile (Patagonia) and the climate stations Punta Arenas, Puerto Williams and Ushuaia (blue dots). See abbreviations in Table 1 
Table 1 Descriptive information on the Nothofagus betuloides chronologies

\begin{tabular}{|c|c|c|c|c|c|c|c|}
\hline Site (abbreviation) & Location & $\begin{array}{l}\text { Altitude m a.s.l. } \\
\text { (slope \%) }\end{array}$ & Aspect & Coordinates & $\begin{array}{l}\text { EPS } \\
\text { Total length } \\
\text { (EPS 0.85) } \\
(>0.75)\end{array}$ & Rbar & $\begin{array}{l}\text { Trees in } \\
\text { chronol- } \\
\text { ogy }\end{array}$ \\
\hline $\begin{array}{l}\text { Alejandro valley } \\
\text { (ALE) }\end{array}$ & Santa Inés Island & $120(10-30)$ & SE, E & $53^{\circ} 41^{\prime} \mathrm{S}, 72^{\circ} 27^{\prime} \mathrm{W}$ & $\begin{array}{l}\text { 1512-2010 (1825- } \\
\text { 2010) } \\
(1702-2010)\end{array}$ & $\begin{array}{l}0.35 \\
0.34 \\
0.35\end{array}$ & 29 \\
\hline $\begin{array}{l}\text { Deseado Fagnano } \\
\text { (DF2) }\end{array}$ & Tierra del Fuego & $300-400(>30)$ & $\mathrm{W}$ & $54^{\circ} 21^{\prime} \mathrm{S}, 68^{\circ} 42^{\prime} \mathrm{W}$ & $\begin{array}{l}\text { 1646-2011 (1731- } \\
\text { 2011) } \\
(1731-2011)\end{array}$ & $\begin{array}{l}0.4 \\
0.41\end{array}$ & 27 \\
\hline Despreciado (DP) & Tierra del Fuego & $250-400(>30)$ & NW, N, NE & $54^{\circ} 21^{\prime} \mathrm{S}, 68^{\circ} 48^{\prime} \mathrm{W}$ & $\begin{array}{l}1643-2011 \\
(\mathbf{1 7 3 9 - 2 0 1 1}) \\
(1717-2010)\end{array}$ & $\begin{array}{l}0.42 \\
0.44 \\
0.44\end{array}$ & 39 \\
\hline $\begin{array}{l}\text { Glaciar Nueva } \\
\text { Zelanda (NZ) }\end{array}$ & Tierra del Fuego & $80(0-30)$ & $\mathrm{W}, \mathrm{NW}$ & $54^{\circ} 42^{\prime} \mathrm{S}, 69^{\circ} 28^{\prime} \mathrm{W}$ & $\begin{array}{l}1810-2012 \\
(\mathbf{1 8 8 0}-\mathbf{1 9 6 0}) \\
(1850-2010)\end{array}$ & $\begin{array}{l}0.4 \\
0.39 \\
0.38\end{array}$ & 11 \\
\hline Lote $10(\mathrm{ST})$ & $\begin{array}{l}\text { Tierra del Fuego } \\
\text { south }\end{array}$ & $230(30)$ & $\mathrm{N}$ & $54^{\circ} 12^{\prime} \mathrm{S}, 68^{\circ} 47^{\prime} \mathrm{W}$ & $\begin{array}{l}1710-2011 \\
(\mathbf{1 7 4 7 - 2 0 1 1}) \\
(1735-2011)\end{array}$ & $\begin{array}{l}0.47 \\
0.45 \\
0.45\end{array}$ & 36 \\
\hline $\begin{array}{l}\text { Valled de los divor- } \\
\text { cios (VD2) }\end{array}$ & $\begin{array}{l}\text { Tierra del Fuego } \\
\text { south }\end{array}$ & $270(>30)$ & $\mathrm{SW}, \mathrm{S}$ & $54^{\circ} 35^{\prime} \mathrm{S}, 69^{\circ} 05^{\prime} \mathrm{W}$ & $\begin{array}{l}1714-2012 \\
(\mathbf{1 8 0 7}-\mathbf{2 0 1 2}) \\
(1794-2012)\end{array}$ & $\begin{array}{l}0.35 \\
0.39 \\
0.37\end{array}$ & 22 \\
\hline
\end{tabular}

Rbar is given in connection to the EPS periods

EPS in column 6 the whole chronology, the period with EPS in bold when EPS $>0.85$ and italics when EPS $>0.7$

samples were subsequently sanded with progressive finer grit from 40 to 1200 (Stokes and Smiley 1968). Under a stereomicroscope with magnification of up to $45 \times$, the samples were dated through assigning a calendar year to each tree ring following the Schulman convention (1956), and visually crossdated (Yamaguchi 1981). Tree-ring widths (TRW) were measured to the nearest $0.01 \mathrm{~mm}$ using the Velmex TA measuring system (Velmex, Inc. Bloomfield NY), and the quality of the measurements was controlled with the software COFECHA (Holmes 1983). Samples belonging to the same tree were averaged. To remove biological noise, i.e., tree age and diameter-related growth trends (so-called age trends), the TRW series were first power transformed (Cook and Petters 1997) and later a 67-year spline detrending (Cook and Peters 1981) using the Signal Free approach (SSF-67, Melvin and Briffa 2008) was applied. From the SSF-67 spline detrended chronologies, principal components were extracted to assess any common signal among the six datasets. Then, the first two principal components were analyzed along the individual site TRW chronologies. Additionally, to avoid spurious correlations due to trends, the chronology indices from the standardized chronology versions were first differenced prior to comparisons with climate data. Expressed population signal (EPS) and the mean inter-series correlation (Rbar) statistics were used to assess the strength of the common signal, an EPS $>0.85$ indicates that the population signal is stronger than that of the individual trees at a given sample size (Wigley et al. 1984). Tree growth variability was compared among the sites for the common period 1815-2010.

\section{Climate data}

To assess the climatic influence on the growth of $N$. betuloides, total monthly precipitation and mean monthly temperature from Punta Arenas $\left(53^{\circ} 9^{\prime} 10^{\prime \prime} \mathrm{S}, 70^{\circ} 55^{\prime} 35^{\prime \prime} \mathrm{W}\right.$, data from Dirección Meteorológica de Chile (DMC); http:// www.meteochile.cl/PortalDMC-web/index.xhtml) for the period 1900-2010 was used. Two additional stations from the Beagle Channel were also used: Ushuaia (GHCN 54 $48^{\prime} \mathrm{S}, 68^{\circ} 08^{\prime} \mathrm{W}$, since 1931 , data from Servicio Nacional de Meteorología, https://www.smn.gob.ar/) and Puerto Williams (DMC 54 $4^{\circ} 55^{\prime} \mathrm{S}, 67^{\circ} 36^{\prime} \mathrm{W}$, since 1969, DMC). Considering the temporal extension of the latter, all time series were truncated to the common period 1969-2000. Representing large-scale atmospheric circulation patterns, we used indices of the SAM (Marshall 2003; data obtained from https://climatedataguide.ucar.edu/climate-data/marsh all-southern-annular-mode-sam-index-station-based) covering the period 1957-2010, and the SOI (Ropelewsky and Jones 1987; data obtained from https://www.ncdc. noaa.gov/teleconnections/enso/indicators/soi/) for the period 1900-2010. Gridded SST and SLP data from the HadISST dataset (Rayner et al. 2003, data obtained from http://www.metoffice.gov.uk/hadobs/hadisst/) and HadSLP (Allan and Ansell 2006, http://www.metoffice.gov. 
uk/hadobs/hadslp2/), respectively, were used for spatial analyses over the 1951-2010 period. SLP from NCAR/ NCEP data was used in the analysis of PC1 and PC2. An overview of the climate and reanalysis data is provided in Table 2.

The interannual associations between the selected climate parameters and tree growth were assessed by calculating the Pearson moment correlation functions on monthly and seasonal data. Seasons include autumn (March-May; MAM), winter (June-August; JJA), spring (September-November; SON) and summer (previous year December-current year February; DJF). Keeping in mind the effects of spurious trends in correlation analysis as mentioned above, the station data was also detrended by means of autoregressive modeling and first differences.

To assess the influences of the atmospheric circulation on tree growth, composite maps of summer (DJF) geopotential heights at $850 \mathrm{mb}$ were created (data from NCEP/NCAR Reanalysis (Kalnay et al. 1996), https:// www.esrl.noaa.gov/psd/data/gridded/data.ncep.reanalysis .pressure.html). Here, all chronologies were filtered with a 20-year high-pass Gaussian filter and years of extreme index values defined as \pm 1 standard deviation from the mean (Pezza et al. 2007). Punta Arenas precipitation and temperature data was treated likewise. The spatial relationships between ring width indices and gridded data were analyzed using the web-based application Climate Explorer (https://climexp.knmi.nl/; Trouet and van Oldenborgh 2013).

\section{Results}

\section{Intra- and inter-site chronology characteristics}

The six newly developed and 67-SSF detrended chronologies show similarities in growth variability with periods of high and low index values (Fig. 2). Common periods of enhanced growth are centered around 1705 for the three longer site chronologies: ALE, DF2, and DP, in addition to 1760 which is also indicated by ST. Periods of higher growth rates were also found for the periods around 1800, 1830 and 1970 in all series, but those are less pronounced in the ALE chronology. Common low-growth periods are found centered around 1665 and 1710 for DP, DF2 and ALE, around 1780 and 1840 in all series except NZ, and around 1940 in all sites. Moreover, the chronologies have certain common extreme negative growth years: the most prominent ones are found in 1769 and 1770 at all sites except ALE and NZ. In the last 20-30 years, tree growth is showing a decreasing trend at all sites except at ALE where tree growth is increasing.

The common signal among all trees at ALE is indicated by an average Rbar of 0.35 over the full chronology length (1514-2012; 499 years, Fig. 2). The chronologies from Tierra del Fuego, DF2, DP and ST, have a similar Rbar evolution with higher values before 1800 . Interestingly, trees at ALE, DF2 and DP all display the lowest common signal among the samples in the early part of the nineteenth century, i.e., between 1803 and 1845, and the highest during the eighteenth century. In turn, trees from NZ located to the

Table 2 Descriptive information of the climate data

\begin{tabular}{|c|c|c|c|c|c|}
\hline & Data & Variable & Coordinates & Period used & Source \\
\hline & Punta arenas & Precipitation, temperature & $\begin{array}{l}53^{\circ} 9^{\prime} 10^{\prime \prime} \mathrm{S} \\
70^{\circ} 55^{\prime} 35^{\prime \prime} \mathrm{W}\end{array}$ & 1900-2010 & Dirección meteorological de Chile \\
\hline 1 & SAM (1) & SLP difference & - & $1957-2010$ & Marshall (2003) \\
\hline 3 & SAM (2) & Reconstruction & & $1866-2005$ & Abram et al. (2014) \\
\hline 3 & SAM (3) & Reconstruction & & $1866-2005$ & Dätwyler et al. (2017) \\
\hline 4 & SAM (4) & Reconstruction & & $1866-2005$ & Fogt et al. (2009) \\
\hline 5 & SAM (5) & Reconstruction & & $1866-2005$ & Villalba et al. 2012 \\
\hline 6 & SOI (6) & Pressure difference & - & 1900-2010 & Ropelewsky and Jones (1987) \\
\hline 7 & NCEP/NCAR & 850 Geopotential height & Global & 1950-2014 & Kalnay et al. (1996) \\
\hline 8 & NCEP/NCAR & SLP & Global & $1950-2010$ & Kalnay et al. (1996) \\
\hline 9 & HadSST3.1.1.1.0 & SST & Global & 1950-2010 & Rayner et al. (2003) \\
\hline 10 & HadSLP2 & SLP & Global & $1850-2014$ & Allan and Ansell (2006) \\
\hline
\end{tabular}

1: https://climatedataguide.ucar.edu/climate-data/marshall-southern-annular-mode-sam-index-station-based

2-5:https://www.ncdc.noaa.gov/paleo-search/study/23130

6: https://www.ncdc.noaa.gov/teleconnections/enso/indicators/soi/)

7-8: https://www.esrl.noaa.gov/psd/data/gridded/data.ncep.reanalysis.html

9: http://www.metoffice.gov.uk/hadobs/hadsst3/data/download.html

10: http://www.metoffice.gov.uk/hadobs/hadslp2/ 
Fig. 2 Nothofagus betuloides TRW chronologies detrended using a power transformation and signal-free approach with a 67-year spline (black thin lines) and its low-pass filtered version (20-year Gaussian filter; bold black lines). Sample depth (gray area) of $n>5$ trees is indicated by red vertical lines. Blue dashed lines show the EPS and its commonly applied threshold of 0.85 (red lines), while the green dashed lines represent the Rbar

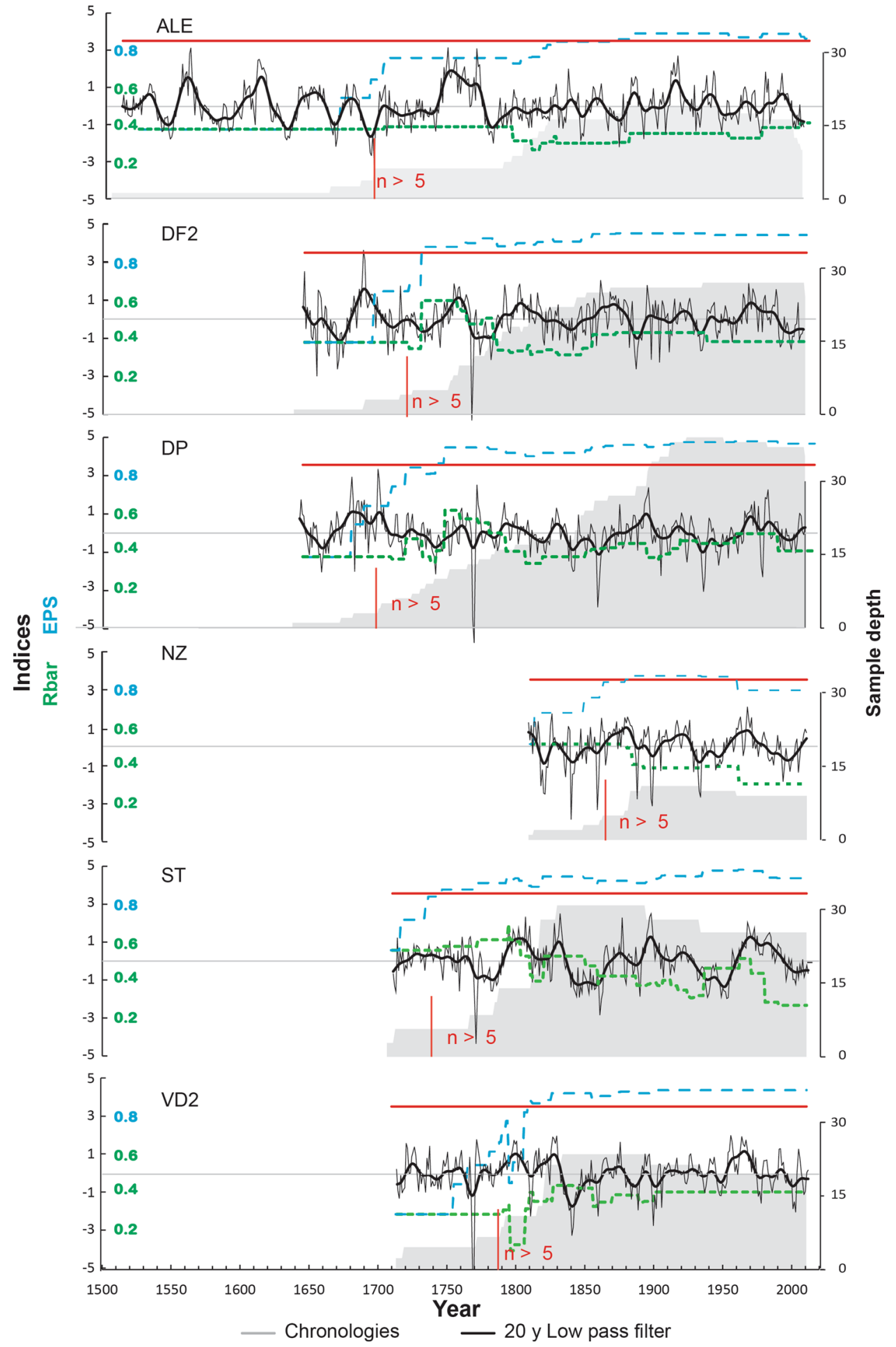

southeast, show a decrease in Rbar after ca. 1870, indicating a progressive loss of common signal strength especially after 1960. Also, trees at ST, located in Tierra del Fuego, displays similar inter-series correlation patterns as the trees at NZ, although the loss of a common signal is extended over the whole chronology length. In general, all chronologies reach
EPS values near or above 0.85 when a sample depth of five trees is reached (Table 1; Fig. 2).

Table 3 shows the inter-site correlations for the period 1815-2010 for the different versions of the high-frequency detrended chronologies (SSF, autoregressive modeled and first differenced versions). In general, correlations decay 
Table 3 Cross-correlation statistics between Nothofagus betuloides chronologies, 67-SSF detrended chronologies in brackets, detrended chronologies with autoregressive modeling in bold, and first differenced data in italics over the common period 1815-2010 with a EPS $>0.85$

\begin{tabular}{llllll}
\hline & ALE & DF2 & DP & NZ & ST \\
\hline DF2 & $(-0.03)$ & & & & \\
& $-\mathbf{0 . 0 4}$ & & & & \\
& -0.03 & & & & \\
DP & $(0.14)^{*}$ & $(0.43)^{* *}$ & & & \\
& $\mathbf{0 . 2 2}^{* *}$ & $\mathbf{0 . 4 6}^{* *}$ & & & \\
& $0.14^{*}$ & $0.62^{* *}$ & & & \\
NZ & $(0.13)^{*}$ & $(0.41)^{* *}$ & $(0.36)^{* *}$ & & \\
& $\mathbf{0 . 1 5}^{*}$ & $\mathbf{0 . 3 7}^{* *}$ & $\mathbf{0 . 3 8} *$ & & \\
& $0.17^{*}$ & $0.29^{* *}$ & $0.26^{* *}$ & & \\
ST & $(0.06)$ & $(0.48)^{* *}$ & $(0.66)^{* *}$ & $(0.38)^{* *}$ & \\
& $\mathbf{0 . 0 8}$ & $\mathbf{0 . 5 3}^{* *}$ & $\mathbf{0 . 6 1} 1^{* *}$ & $\mathbf{0 . 4 1} * *$ & \\
& $0.14^{*}$ & $0.67^{* *}$ & $0.72^{* *}$ & $0.34^{* *}$ & \\
VD2 & $(0.1)$ & $(0.41)^{* *}$ & $(0.41)^{* *}$ & $(0.39)^{* *}$ & $(0.55)^{* *}$ \\
& $\mathbf{0 . 1 4}$ & $\mathbf{0 . 4 4}^{* *}$ & $\mathbf{0 . 5 1} * *$ & $\mathbf{0 . 4 4} * *$ & $\mathbf{0 . 5 5} * *$ \\
& 0.07 & $0.41^{* *}$ & $0.43^{* *}$ & $0.46^{* *}$ & $0.42^{* *}$ \\
\hline
\end{tabular}

Correlations exceeding significances of $95 \%$ and $99 \%$ are indicated by one and two stars, respectively

with increasing distance between the sites, with the best agreement found between the neighboring sites DP and ST.

The correlations between the chronologies vary, but reaches consistently higher values between ST, DP and DF2 and also VD2 see Table 3. 67-SSF detrended chronologies had best pair correlation of up to $r=0.55(p<0.01)$ between ST and VD2 and $r=0.66(p<0.01)$ between ST and DP. For the high-passed filtered chronology versions (first differences), highest correlation values of $r=0.72(p<0.01)$ were found between DP and ST. These results agree with the results obtained with the principal component analysis. The first principal component (PC1) (up to $46.6 \%$ of the total variance) includes chronologies from the sites ST, DP, DF2, VD and NZ with positive loadings of $0.86,0.79,0.77$, 0.74 and 0.5 , respectively. The second principal component (PC2) comprises the sites ALE and NZ with positive loadings of 0.88 and 0.48 , respectively, explaining $18.7 \%$ of the total variance. These results are presented in supplementary Tables 8 and 9 .

\section{Climate data and tree rings}

The climate-growth relationship between all site chronologies, as well as the two leading PCs, and precipitation and temperature data from Punta Arenas station (1900-2010 CE) is shown in Fig. 3. The climate signal between the individual sites varies considerably between individual months and seasons. To summarize, tree growth at two sites is significantly positively correlated with summer temperatures with $r=0.34(p<0.05)$ at the ALE site and $r=0.19(p<0.05)$ at the DP site. Previous year's autumn temperatures benefited tree growth at three sites: DF2, NZ and VD2 (Fig. 3b, c and $\mathrm{f}$ ). Considering precipitation, significant correlations were obtained for the TRW chronology at the highest and easternmost site DF2 (Fig. 3c). Here, tree growth correlated significantly negatively with July and winter precipitation with $r=-0.22$ and $-0.2(p<0.05)$, respectively, and significantly positively with rainfall amounts during November $(r=0.19$ for $p<0.05)$. Overall, high rainfall amounts during winter were detrimental, whereas high rainfall amounts during spring were beneficial for tree growth at the DF2 site.

The obtained climate responses for the individual sites are reflected by the two leading PCs (Fig. 3g, h). For PC 1 , significant positive correlations were found for autumn temperature $(r=0.27 ; p<0.05)$ and summer precipitation $(r=0.22 ; p<0.05)$. Contrary, tree growth at the sites contributing to $\mathrm{PC} 2$ were significantly positively influenced by warm summer temperatures $(r=0.38, p<0.01)$.

Climate-growth response pattern as presented above for the Punta Arenas station over the entire twentieth century slightly changed when considering the shorter period 1969-2010 and including two additional stations and the gridded CRU TS 3.23 data (Fig. 4). The site chronologies DF2, NZ, ST, VD and PC1 showed significant positive correlations $(p<0.05)$ with summer precipitation especially when using the Punta Arenas station and CRU data and for the spring season when using the Puerto Williams station. Moreover, for the same sites and both PCs, significant negative correlations were found with rainfall amounts during the winter season (highest for Punta Arenas and CRU data for the site chronologies DF2, ST, VD2 and PC1 and for Ushuaia station for the TRW chronology for NZ). Regarding temperature, significant positive correlations were found for almost all sites and PC2 and the Punta Arenas and Puerto Williams station data during the summer. Contradicting correlation results are found for the CRU temperature data, which correlated significantly negatively with the chronologies at DP, VD2 and the two PCs during summer.

Correlations between tree growth and SAM and SOI indices are shown in Fig. 5. The relationships between the tree growth and the SAM and SOI indices are barely significant and for some sites, negative associations between TRW and the indices during the current growing season were obtained (Fig. 5a-h). DF2 (Fig. 5c) displays the highest correlations with SAM, being positive and significant in March of the year prior to growth $(\mathrm{r}=0.36, p<0.01)$ and negative in November and March $(r=-0.36$ and $r=-0.41 p<0.01)$ in the current year of growth, as well as during the summer season. Tree growth at DP (Fig. 5e) is positively correlated with SAM in February of the year prior to growth $(r=0.39$, $p<0.01$ ), whereas significant negative correlations for VD2 (Fig. 5d) are found for the months of August and December ( $r=0.30$ and $r=0.29, p<0.05$, respectively). TRW 

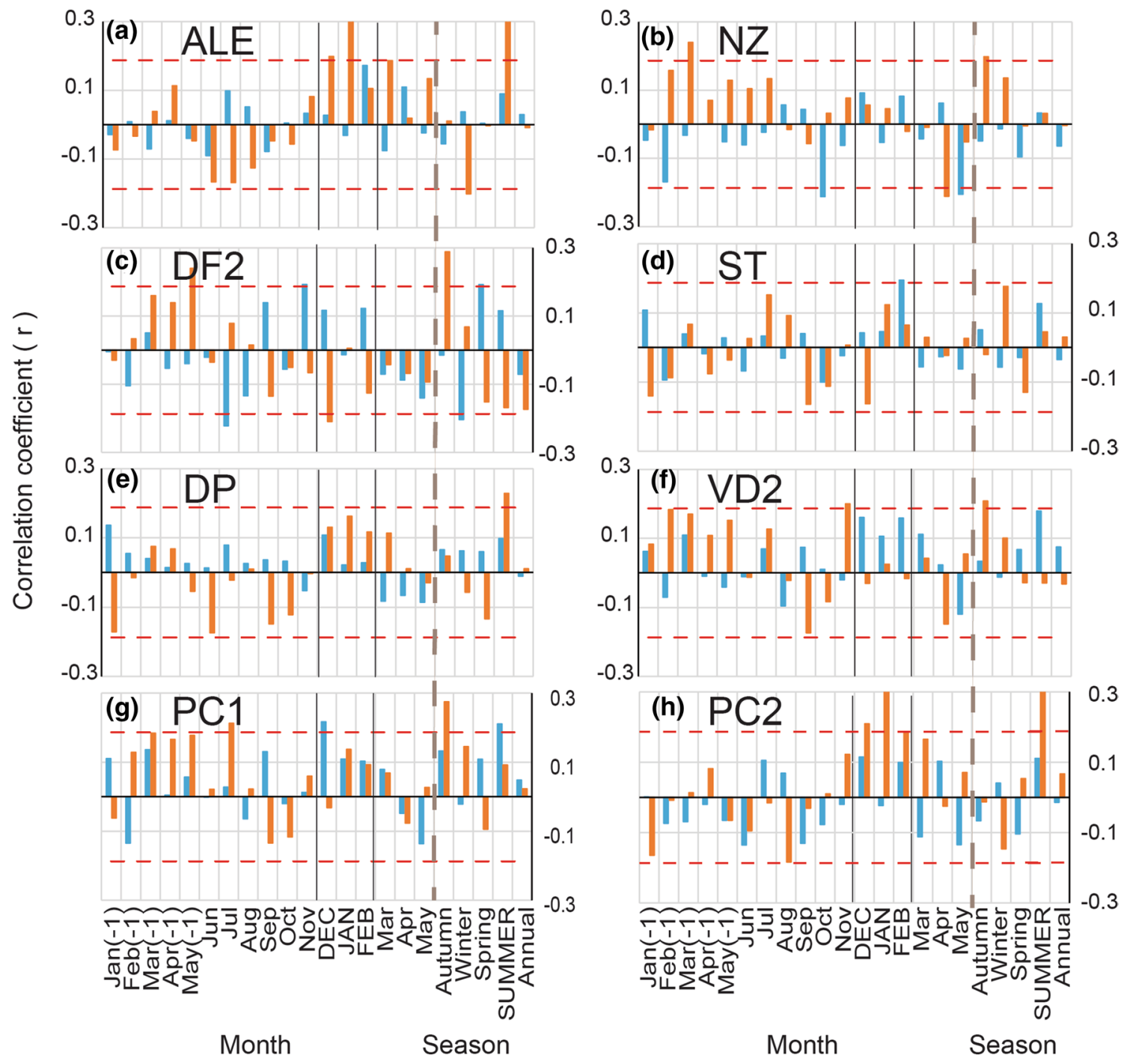

Precipitation $=$ Temperature $-\cdot p<0.05$

Fig. 3 Correlation coefficients $(\mathbf{a}-\mathbf{h})$ between detrended Nothofagus betuloides chronologies, and its principal components 1 and 2 and precipitation (blue bars) and temperature (red bars) data from Punta Arenas station (1900-2010). Season averages Autumn: March to May; Winter: June to August; Spring: September to November and

chronologies are generally negatively correlated with the SOI when considering the period 1866-2010 CE (Fig. 5), being significant only for ALE for November and January and the spring season $(r=-0.18, r=-0.22$ and $r=-0.18$, respectively, $p<0.05)$ and for PC2 for both November and January $(r=-0.21$ and $r=-0.22, p<0.05)$.

For correlations with the reconstructed SAM over longer time period (1866-2005) (Table 4 and supplementary Tables 6 and 7), the highest agreement was found between ST and the SAM reconstruction from Villalba et al. (2012) with $r=0.38(p<0.01)$, followed by Dätwyler et al. (2017)
Summer: December to February; Month in the previous growing season are marked with $(-1)$. Month in capitals correspond to current growing season. Seasonal averages are shown to the right from the vertical dashed lines

with $r=0.35$ ( $p<0.05)$. All chronologies, with the exemption of ALE, correlated significantly with one of the reconstructions $(p<0.05$ or $p<0.01)$, and at different frequency bands. For example, DF2 correlated at $r=0.25(p<0.01)$ when using first differenced records (interannual frequency) with Villalba et al. (2012) SAM reconstruction. None of the reconstructions from Fogt et al. (2009) or Abram et al., (2014) correlated significantly with site chronologies for this time interval. PC2, however correlated with Abram et al. 


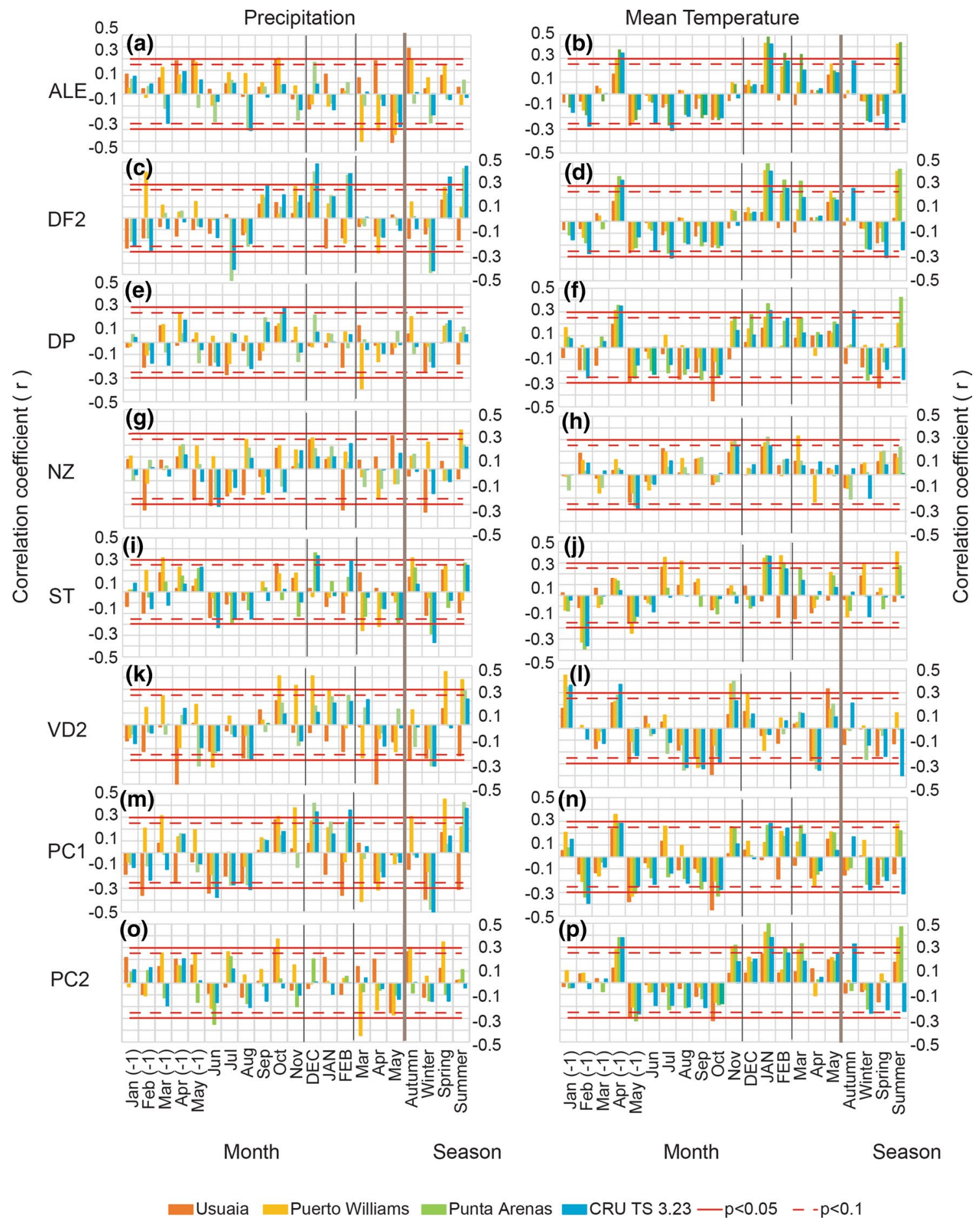

Fig. 4 Correlation coefficients (a-p) between detrended (first difference) Nothofagus betuloides chronologies, principal components 1 and 2 and precipitation and temperature data from Punta Arenas

station, CRU TS 3.23, Ushuaia station and Puerto Williams station (1969-2010). Seasonal averages are shown to the right from the vertical dashed lines. Abbreviations as in Fig. 3

(2014) $r=-0.22(p<0.05)$ (not shown). It has to be noted that correlations over a longer period and for the early period 1866-1934 between the SAM and TRW indices are positive,

whereas for the latter period 1935-2005 correlations turn negative (see supplementary Tables 6 and 7 for details). 
Fig. 5 Correlation coefficients (a-p) between Nothofagus betuloides chronologies and atmospheric indices detrended data (linear fit) and SAM Marshall $(n=53)$ and Southern Oscillation Index $(n=111)$. Bold capitals indicate current growing, shaded areas indicate warm season. Seasonal averages are shown to the right from the vertical dashed lines. Abbreviations of seasonal averages as in Fig. 3

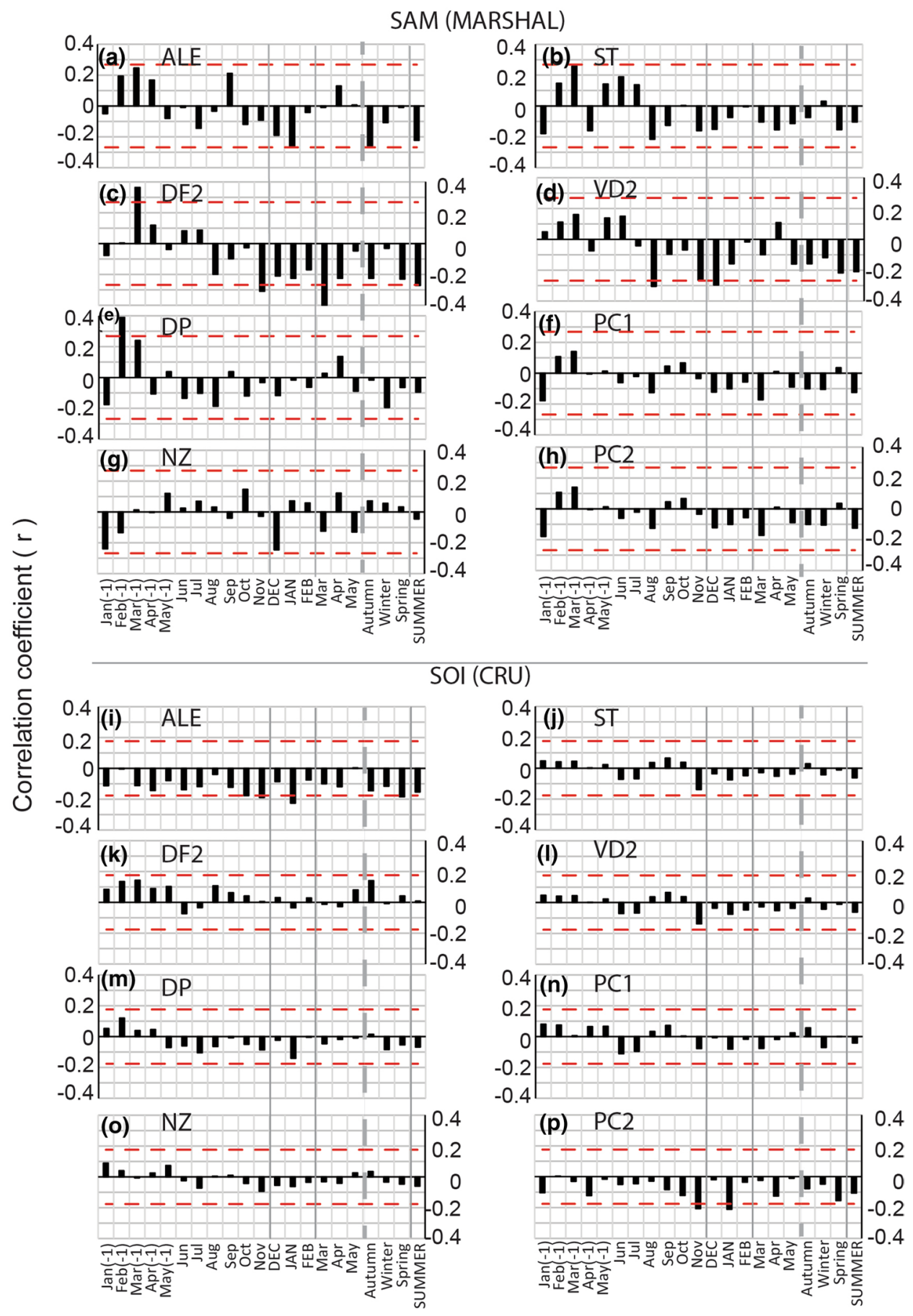

\section{Spatial field correlations}

The spatial field correlations between the TRW chronologies and gridded SST averaged over January to February suggest relevant relationships (Fig. 6), although they vary among the chronologies. All chronologies, except NZ, and PC1 show significant positive correlations with SST in the Southern Ocean (in the spatial analysis $p<0.05$ at each grid cell), in the area comprising the Amundsen, Bellingshausen and Weddell Seas (Fig. 6a-h). Significant positive correlations with Tropical Pacific SST are found for ALE, DF2, DP and NZ (Fig. 6b-d, f), while significant negative correlations with SST across the subtropical Pacific and Atlantic Oceans between $20^{\circ} \mathrm{S}$ and $56^{\circ} \mathrm{S}$ are found for DF2, DP, ST, NZ, VD2 and PC 1 (Fig. 6b, d-f). Moreover, $\mathrm{PC} 1$ and $\mathrm{PC} 2$ correlate significant positive with the southwestern West Atlantic regions (Fig. 6g-h). 
Table 4 Cross-correlation statistics between Nothofagus betuloides chronologies and published reconstructions of southern annular MODE (1866-2005)

\begin{tabular}{|c|c|c|c|c|c|c|}
\hline & ALE & DF2 & DP & $\mathrm{NZ}$ & ST & VD2 \\
\hline Dätwyler et al. 2017 & $\begin{array}{l}-\mathbf{0 . 0 9} \\
-0.14\end{array}$ & $\begin{array}{l}\mathbf{0 . 0 6} \\
0.17^{*}\end{array}$ & $\begin{array}{l}\mathbf{0 . 1 5} \\
0.2 * *\end{array}$ & $\begin{array}{l}\mathbf{0 . 1 7} \\
0.12\end{array}$ & $\begin{array}{l}\mathbf{0 . 3 5} \mathbf{5}^{* *} \\
0.27^{* *}\end{array}$ & $\begin{array}{l}\mathbf{0 . 1 3} \\
0.05\end{array}$ \\
\hline Fogt et al. 2009 & $\begin{array}{l}\mathbf{0 . 0 3} \\
0.08\end{array}$ & $\begin{array}{l}\mathbf{0 . 1 1} \\
-0.03\end{array}$ & $\begin{array}{l}\mathbf{0 . 0 6} \\
0.07\end{array}$ & $\begin{array}{l}\mathbf{0 . 0 6} \\
0.05\end{array}$ & $\begin{array}{l}\mathbf{0 . 0 8} \\
0.04\end{array}$ & $\begin{array}{l}\mathbf{0 . 0 1} \\
0.05\end{array}$ \\
\hline Villalba et al. 2012 & $\begin{array}{l}\mathbf{0 . 0 3} \\
0.15\end{array}$ & $\begin{array}{l}\mathbf{0 . 1 1} \\
0.25^{* *}\end{array}$ & $\begin{array}{l}\mathbf{0 . 2 1} * \\
0.17^{*}\end{array}$ & $\begin{array}{l}\text { 0.28*** } \\
0.19^{*}\end{array}$ & $\begin{array}{l}\mathbf{0 . 3 8}^{* *} \\
0.27^{* *}\end{array}$ & $\begin{array}{l}\mathbf{0 . 1 7} * \\
0.12\end{array}$ \\
\hline Abram et al. 2014 & $\begin{array}{l}\mathbf{0 . 1 4} \\
-0.04\end{array}$ & $\begin{array}{l}-\mathbf{0 . 0 8} \\
-0.12\end{array}$ & $\begin{array}{l}\mathbf{0 . 0 5} \\
0.07\end{array}$ & $\begin{array}{l}-\mathbf{0 . 0 3} \\
0.19\end{array}$ & $\begin{array}{l}-\mathbf{0 . 0 3} \\
-0.04\end{array}$ & $\begin{array}{l}-\mathbf{0 . 1 2} \\
-0.07\end{array}$ \\
\hline
\end{tabular}

67-SSF chronologies detrended data with autoregressive modeling in bold, first differenced data in italics) Correlations exceeding significances of $95 \%$ and $99 \%$ are indicated by one and two stars, respectively $* p<0.05$

$* * p<0.01$
The spatial field correlation maps between tree growth and warm season (in this case November to February) SLP indicate an influence of a SLP dipole pattern (Fig. 7). Significant positive correlations with SLP over the Drake Passage and partially on the Weddell Sea are observed for all chronologies, but less clear for PC 1 and 2. Significant negative correlations with SLP north of $40^{\circ} \mathrm{S}$ in the Pacific, over the American continent and in the Atlantic were evident particularly with the ALE and DF2 site chronologies (Fig. 7a, b), and to some extent at NZ, ST and VD2 (Fig. 7d-f). PC1 matches in opposite sign the correlation patterns observed for DF2 (Fig. 7b) while PC2 indicates negative correlations with the region over Drake Passage into the Weddell Sea.

In Fig. 8, composite maps of $850 \mathrm{mb}$ geopotential height anomaly patterns during years with positive $(+)$ and negative (-) extreme growth and precipitation (Fig. 8d) and temperature (Fig. 8h) extremes from the Punta Arenas station record are shown. Examining the large-scale geopotential height patterns, the meridional pressure differences which are more evident during negative extreme growth years are organized in latitudinal bands resembling the SAM structure, while during positive extreme years wave train patterns are evident.

\section{Discussion}

Due to the large heterogeneity in topography and thus microsite conditions in the study area, the growth characteristics of the TRW chronologies vary among the sites, even within short distances (Fig. 2; Table 3). This is in line with previous findings (Boninsegna et al. 1989; Soto-Rogel and Aravena 2017). Of the six newly developed chronologies, ALE shows the least agreement with the other sites, probably due to its greater distance to the other sites and the strong oceanic influences affecting greatly the western flank of the Patagonian Archipelago (e.g., Carrasco et al. 2002). Differences were also found when comparing the TRW chronologies from Tierra del Fuego Island (DF2, DP and ST) to the sites NZ and VD2 that are located further south. Similar patterns were previously noted by Soto-Rogel and Aravena (2017), with their chronologies in Cordillera Darwin when compared to those of Tierra del Fuego used in Villalba et al. (2012). These differences in the correlations among the chronologies are evident in the high-pass filtered as well as the detrended chronology versions (SSF67) which retain a certain degree of low frequencies. In addition, the strength of the common growth signal in the chronologies varies through time: the Rbar values are higher for the sites (ALE, DF2 DP and ST) during the eighteenth century, compared to the nineteenth century. On the contrary, VD2 (one of the southernmost sites) displays higher Rbar values during the latter period. These differences in Rbar are, however, not visible in the EPS values which remain high throughout these periods for all chronologies. Hence, a strong climate signal will remain stable throughout the chronology length and is enhanced at higher sample replication (Büntgen et al. 2012), while in the case of the chronologies in this study, biological noise may increase while sample depth is low.

\section{Precipitation and temperature influences on tree growth}

Considering the long-term data from Punta Arenas, there is no clear common climate response pattern among all six TRW chronologies, which is likely a result of the site and ecological conditions at microsite level. Thus, higher correlations were found for growing season precipitation (spring and summer) at two sites DF2 and ST (also shown for PC1) when compared to the long Punta Arenas data covering the past 110 years (Fig. 3). This signal was similar or enhanced when considering shorter station data including Ushuaia and Puerto Williams (located by the Beagle Channel, Punta Arenas and gridded CRU TS3.23 data for the shorter period 1969-2000 CE; Fig. 4). Then, $\mathrm{NZ}$ and VD2 indicate increased positive correlations with 
Fig. 6 Spatial correlation maps between January to February (all sites except ST) averages of HadlSST1 sea surface temperature and $N$. betuloides chronologies (detrended data) a ALE; b DF2; c DP; d NZ; e ST; f VD $2 ; \mathbf{g}$ PC 1 ; $\mathbf{~ P C} 2$ for the period between 1951 and 2012. Only for the ST site, February to March HadlSST1 sea surface temperatures were averaged.

The colored cells indicate $p<0.05$
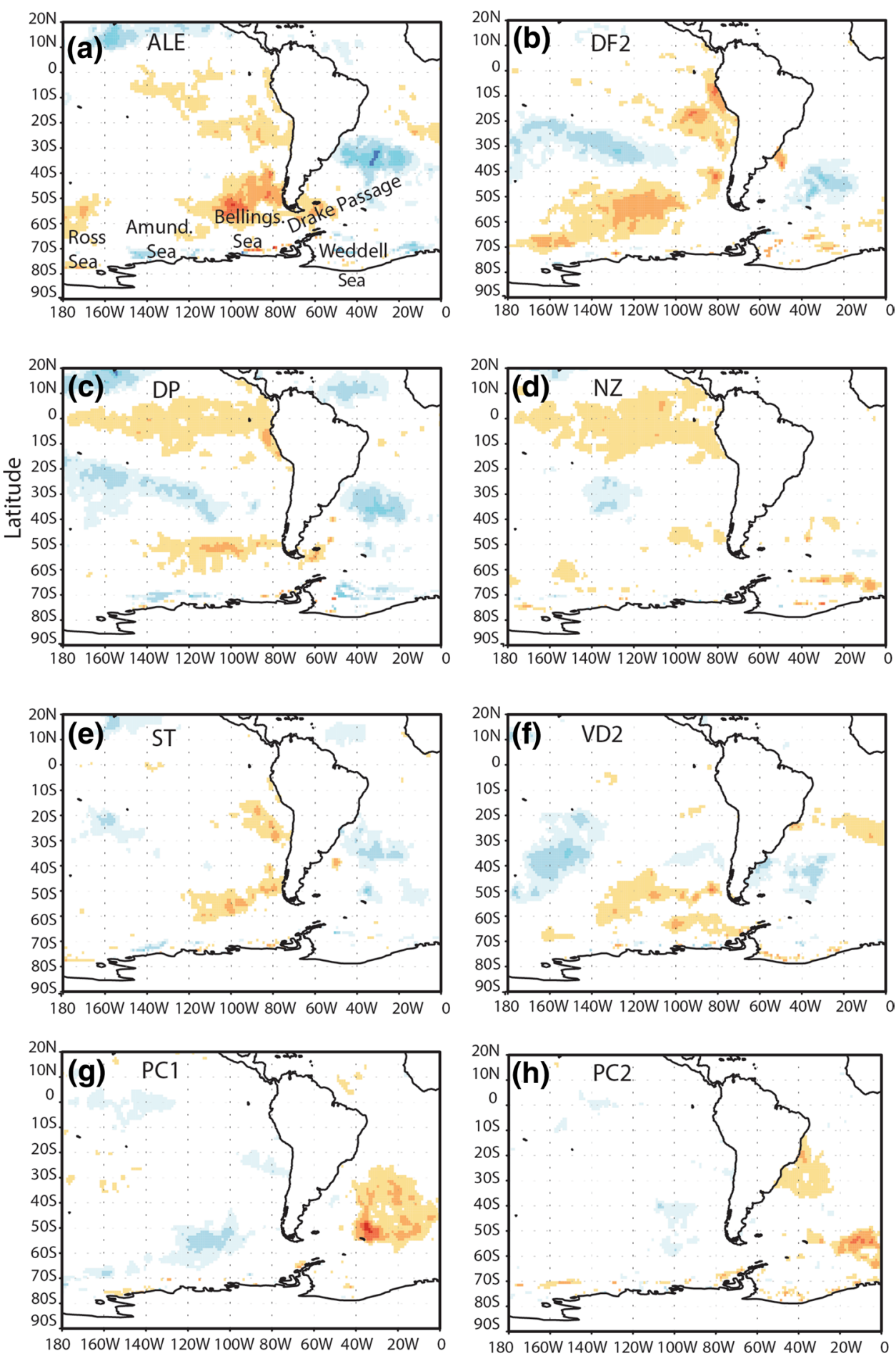

Longitude

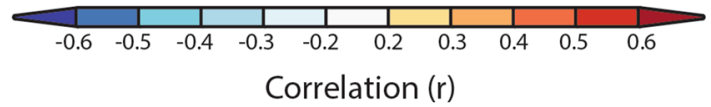

precipitation during the warm season, (spring and summer time and individual months; for example, October, November, January and February) $(p<0.05)$. Moreover, precipitation in winter or autumn also becomes significant for these sites. Changes in the relationships between TRW and precipitation through time may imply enhanced 
Fig. 7 Spatial correlation maps between sea level pressure (HadSLPr; Harris et al. 2002) and Nothofagus betuloides chronologies (detrended data) a ALE; b DF2; c DP; d NZ; e ST; f VD2; $\mathbf{g}$ PC1; h PC2 for November to February and the period 1951-2012, $p$ field $<10 \%$ and $p<0.05$ for the colored grid cells
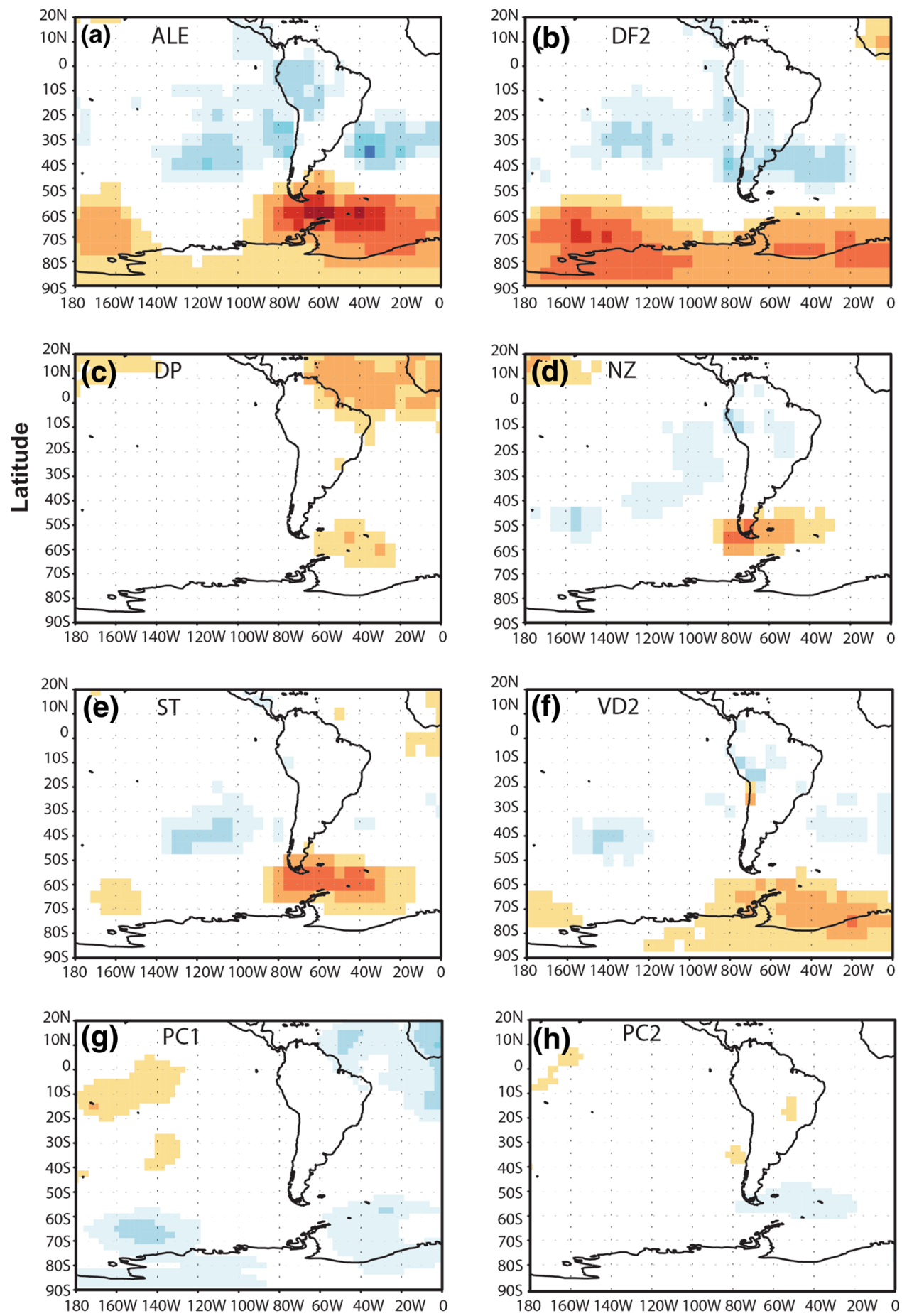

Longitude

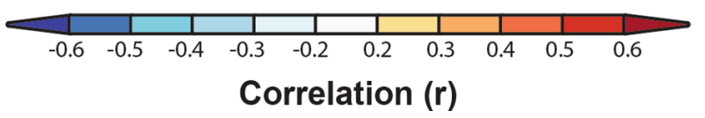

importance of this variable on tree growth maybe as a response to increasing aridity, or a higher frequency of droughts alike that was reported for the area of Punta Arenas (see González-Reyes et al. 2017). The positive influence of precipitation on tree growth at DF2, ST and VD2 may be due to the combination of several factors affecting the microsite hydrology: soil depth, steepness of the slopes $(>30 \%)$, and wind speeds that usually increase 

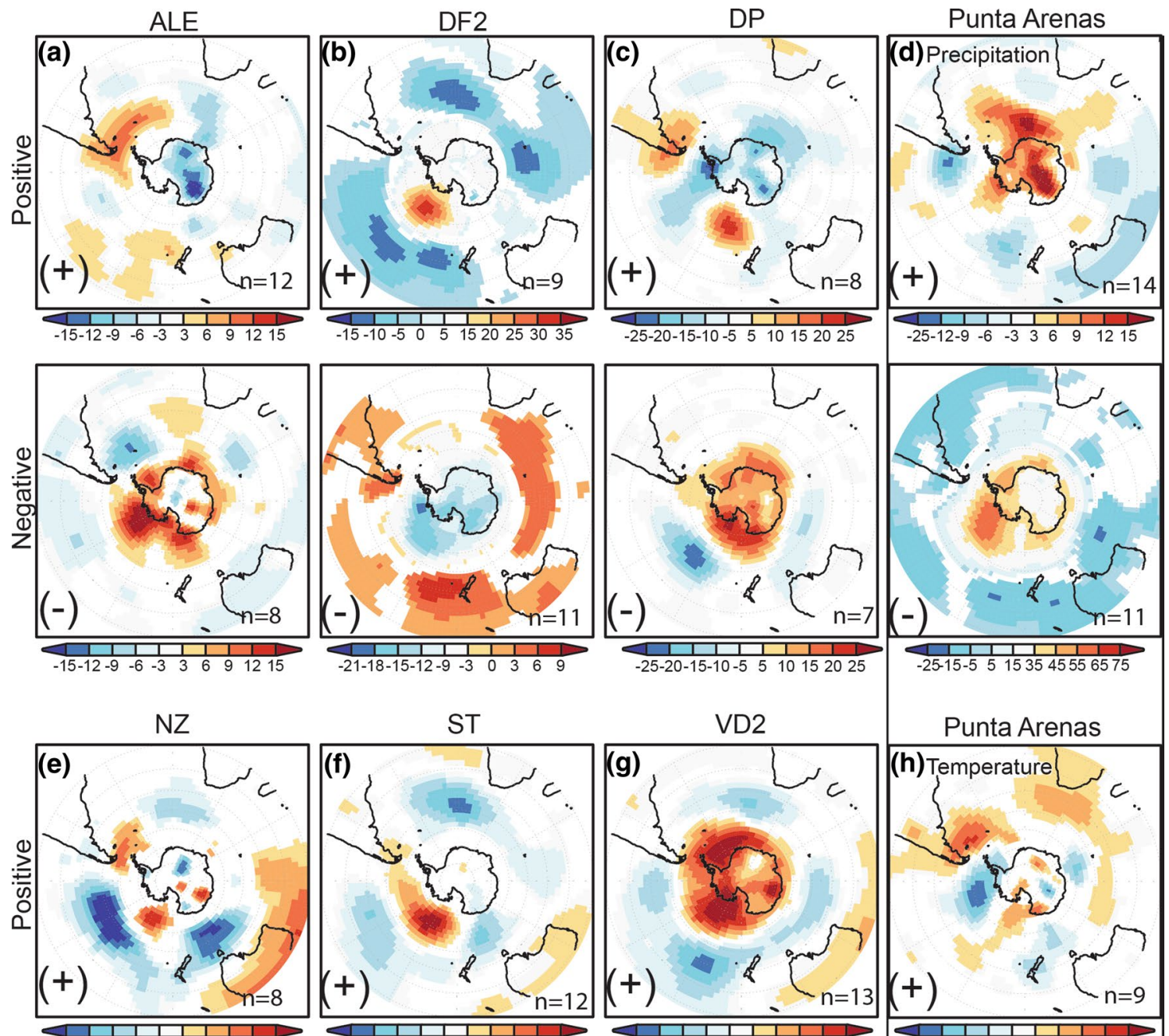

Punta Arenas
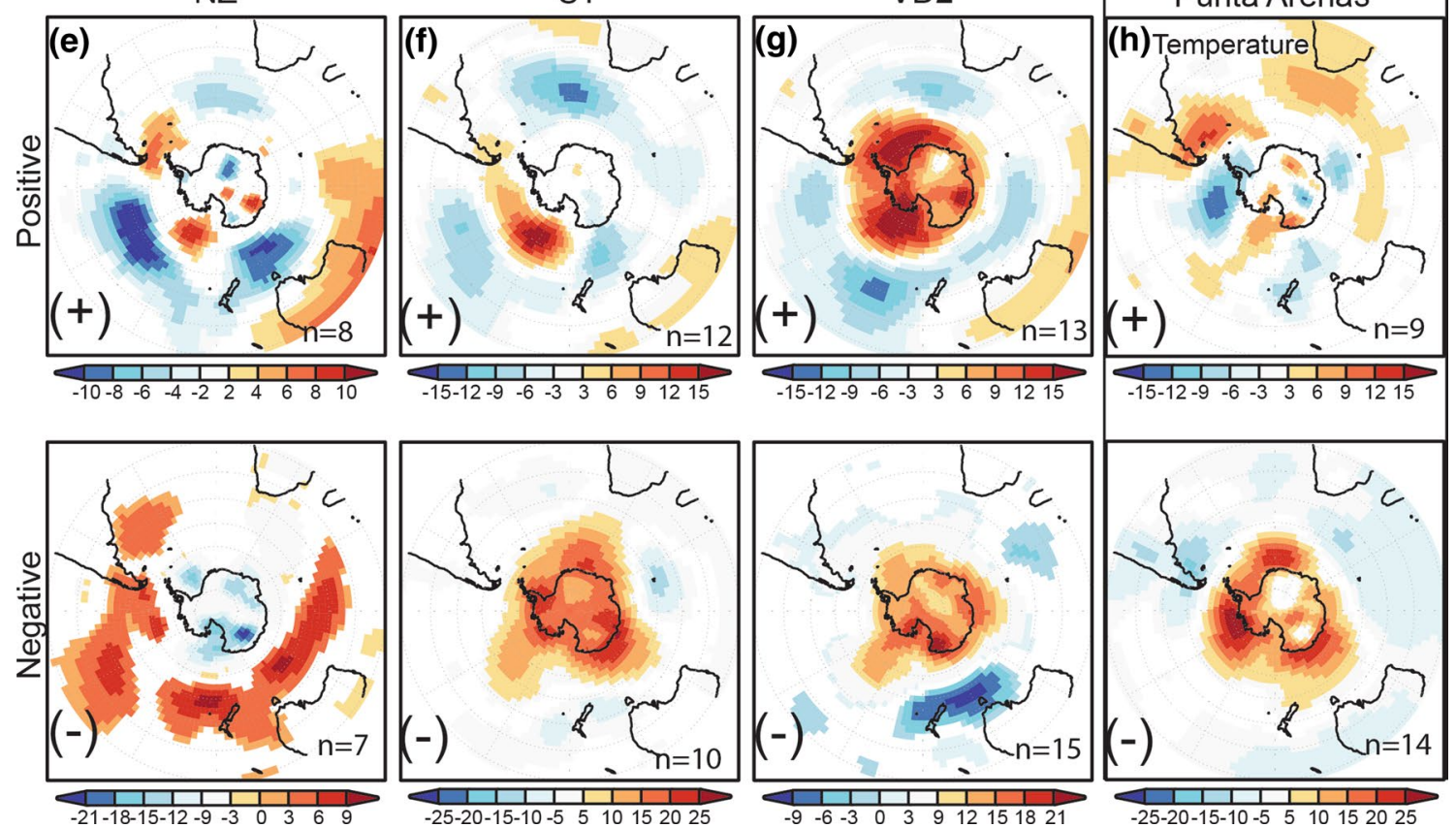

Fig. 8 Composite $850 \mathrm{mb}$ geopotential height maps (NCEP/NCAR data, Kalnay et al. 1996) for DJF and extreme growth years [values above (below) 1 standard deviation] between 1948 and 2002 and extreme precipitation and temperature recorded at Punta Arenas

in the warm season (Carrasco 2002; Garreaud et al. 2013; Schneider et al. 2003). The negative precipitation signal during the growing season (NZ and PC1) may be a response to enhanced cloudiness which affects photosynthesis negatively (Stine and Huybers 2014). In turn, negative correlations with winter precipitation can be related to (extreme years are listed in table S-I). For each dataset, panel above (below) correspond to positive (negative) extreme years at the site a ALE, b DF2, c DP, d Punta Arenas, e NZ and f ST, g VD2 and h Punta Arenas. Units are in $\mathrm{mb}$ and note changes in scales

excessive moisture stored at the sites prior warm season, or alternatively increased snow cover, delaying optimal growing conditions at the start of the growing season (see e.g., Linderholm and Chen 2005; Tranquilini 1979).

The positive summer temperature signal at sites located at high latitude can be expected, but only ALE and DP (PC2) 
indicated this trait if only the long-term data set is considered. All chronologies but VD2 indicated positive response to summer temperature when all datasets are analyzed in the shorter time interval (after 1969). Moreover, the negative correlations with temperature in winter and early spring prior to the growing season observed at ALE, DF2, DP, VD2 and PCs can be explained by different mechanisms: high winter temperatures can trigger early bud burst before growing season, making trees prone to suffer frost and hail damages from cold surges (Boninsegna et al. 1989). Warm winter temperatures also induce early snow melt, affecting the water storage that will be available in the growing season; this would be more important for dry sites (Llancabure 2011, and; Soto-Rogel and Aravena 2017). Moreover, warmer conditions may facilitate disturbances caused by forest pathogens (see Logan et al. 2003 and references there in) such as Ormiscodes sp., which is connected to warmer and drier winter and spring seasons in southern Chile and Argentina (Veblen et al. 1996a, b). In addition, SAM variability was argued to affect positively the frequency of insect outbreaks in southern Nothofagus forests (Paritsis and Veblen 2011) representing a large-scale control on components of the ecosystem in the region.

The differences in the observed climate signals when testing different datasets suggest problems on the quality of the station data (Villalba et al. 2003; Garreaud et al. 2013) but also that Punta Arenas is too far located from the sites studied. Nevertheless, the changes of the climate signal can be real and provoked by large-scale oceanic and atmospheric circulation affecting the moisture (temperature) distribution in the area (see Turner et al. 2016 and; Villalba et al. 2012). Thus, considering the strong west-east precipitation gradient (Carrasco et al. 2002; Schneider et al. 2003; Garreaud et al. 2013), stronger associations between the eastern chronologies and precipitation were expected. However, our results are not conclusive, partly due to the barely significant results of correlation tests, and to the reduced amount of sites used here.

\section{Regional climate signal}

Focusing on the regional climate signal, all chronologies correlated positively with each other, except ALE. This suggests a different climate control on tree growth at this particular site, whereas similar climatic responses are expected to be driven by a similar climate regime at the other five sites. This is further illustrated by the PCs and the common signal they detect. The correlation decay of the site chronologies with increasing distance is expected and most likely enhanced in this highly topographically diverse environment with different microsite characteristics, which in turn causes this array of climate signals among sites. A typical example is that of DF2 and DP in Tierra del Fuego displaying opposite correlations with summer temperatures (Figs. 3c, e and $4 c-f)$. On account of Punta Arenas' long observation record, the chronologies display little similarities in the climate signal, while common patterns are observed if the shorter series are used (see Figs. 3, 4). Otherwise, it suggests that a common signal among the chronologies does not necessarily depend only on these variables in the long-term context. For instance, wind as a third variable affecting tree growth can be suggested, acting through modulation of precipitation and temperature regimes during the warm season. It can be noted that westerly winds and precipitation are positively correlated (Garreaud et al. 2013) and that wind has been shown to affect tree growth negatively (Villalba et al. 2003). In this sense, the interpretation of the wind effects in the ecosystem is rather complicated since it brings moisture as it is positively correlated with the precipitation (Carrasco 2002; Schneider et al. 2003; Garreaud et al. 2013) but on the other hand, leads to high evaporative conditions provoking increased rates of evapotranspiration at the microsites (Villalba et al. 2003; Garreaud et al. 2013). In our study, correlations using diverse wind parameters were tested on all TRW chronologies, however, the results were not significant.

Another factor, SLP affects wind temperature and precipitation with significant effects (Schneider et al. 2003). Garreaud et al. (2013) using reanalysis data argued that a SLP dipole determines different regimes of precipitation in southern Patagonia, including the Archipelago of Tierra del Fuego. This implies that our TRW chronologies spread through the archipelago may have different climatic controls in the summer season. More on SLP is discussed in the following sections.

\section{Evidence of climate signals related to SAM and SOI in the tree rings}

Only two chronologies (VD2 and DF2) indicated weak significant negative effects of SAM index on tree growth, contrasting with results shown in Villalba et al. (2012) for Tierra del Fuego. This result can be explained by (a) that the microsite conditions enhance noise-dampening SAM signal and (b) that the study area is located in the main path of the westerly wind flow, restricting the sensitivity to SAM years.

Further, linking tree growth at the six sites and the four reconstructed SAM indices yielded ambiguous results, reaching higher values with the tree-ring-based reconstruction from Villalba et al. (2012), while poor results were found when comparing with SAM versions from Fogt et al. (2009), Abram et al. (2014) and Dätwyler et al. (2017) (Table 4). These contrasting results may be a consequence of the climate sensitivity of the diverse proxies used to reconstruct the index, the season targeted and stationarity issues reported for this index (see Silvestri and Vera 2003, 2009; 
Dätwyler et al. 2017). Moreover, the study area is affected by a rather concomitant set of atmospheric and oceanic modes (Villalba 2007, Turner et al. 2016) and SAM accounts for only ca. $22 \%$ of the atmospheric variability of the southern hemisphere (Gong and Wang 1999). Moreover, differences in the regimes of the Pacific Basin are also important through time (Turner et al. 2016). It is remarkable that after 1950 s, correlations with the index are negative, whereas they are positive for the whole length (1866-2005) (Table 4, and supplement Tables 6 and 7).

The spatial field correlation maps between TRW and SLP (Fig. 7a, b, f) indicate the importance of the southern ocean pressure fields, with a SAM structure visible as a dipole pattern (north of $40^{\circ} \mathrm{S}$ and south of $50^{\circ} \mathrm{S}$ ). Further, coincidence with the negative phase of SAM can be identified south of $50^{\circ} \mathrm{S}$ in Fig. 7a, b. Other SLP structures, similar to those shown in Villalba et al. (1997, 2003), are indicated for the rest of the chronologies regarding the high pressure nodes centered over the Drake Passage and the Weddell Sea. Moreover, the composite maps of geopotential height during extreme years of low tree-growth indices and climate data from Punta Arenas also indicate this latitudinal bands structure coinciding with the structure of the composite maps for low-growth extremes indicating a positive phase of SAM for DF2 and NZ, but also a negative phase for ALE, DP, ST and VD2. The latter can be explained by the low pressure anomalies locally distributed in the proximity of the South American continent (e.g., Fig. 8 a, c, d, f-h) and the anticyclonic circulation, with consequent southerly flow into the continent with the dominance of cold polar temperatures as indicated in Fig. 8h (see also Kwok and Comiso 2002). These findings indicate that neither positive nor negative strong SAM years is beneficial for tree growth, with exemption of VD2. Years of extreme positive growth are explained by train wave structures in the southern ocean instead.

The influences of the Tropical Pacific on tree growth north of $45^{\circ} \mathrm{S}$ has been presented previously (Villalba et al. 2001, 2003; Christie et al. 2009), while the potential influence of the SST in the Southern Pacific (about Amundsen and Bellingshausen Seas and Weddell Sea) to the south Atlantic on tree growth in the southern Patagonian coast has been largely ignored. Hence, effects of SOI on the chronologies are moderate and negative. Here, we present the first evidences indicating effects of the tropical and subtropical pacific in the tree growth patterns (Figs. 5i-p, 6). From these, DP and NZ, indicate correlation patterns with SST that correspond to a typical El Niño SOI structure, emphasizing the El Niño 3-4 region and closer to South America in the south. The SOI modulates the activity of the subtropical Pacific anticyclone (Aceituno 1988, 1989), which in turn affects atmospheric circulation patterns in South America. This suggests meridional heat transport to higher latitudes; and eastward flow of surface heat from southern Pacific downstream to the continent driven by the westerly wind flow (Lee et al. 2010; Garreaud et al. 2009, 2013). In spring and early summer, such heat transport would induce warmer conditions on the continent favoring tree growth, while later in the summer would cause cooling (Garreaud et al. 2013), and probably increase precipitation (Carrasco 2002; Schneider et al. 2003). The SOI index is negatively correlated to the SST offshore to the southern Pacific in November (not shown), thus explaining the negative correlations with tree growth.

Only two extremes years in the tree-growth patterns coincide with extreme years of Tropical Pacific variability: 1968 and 1972 (Table 5). Moreover, extreme growth years

Table 5 Extreme growth years exceeding \pm 1 standard deviation of tree ring chronologies after 1948 used for 850 mb geopotential height NCEP/ NCAR composite maps

\begin{tabular}{llc}
\hline Chronology & + & - \\
\hline ALE & $1954,1966,1967,1973,1974,1981,1982,1984,1994$, & $1949,1950,1962,1971,1978,1979,1980,1985$ \\
& 2007 & \\
DF2 & $1954,1967,1971,1974,1982,1983,1991,1992,2007$ & $19481959,1962,1970,1978,1981,1987,1993,1994$, \\
& & 1995,2002 \\
DP & $1974,1977,1981,1982,19831984,2007,2008$ & $1955 ; 1955 ; 1962 ; 1978 ; 1980 ; 2004 ; 2004$ \\
NZ & $1963,1964,1969,1972,1981,1991,1993,2005$ & $1959,1966,1967,1973,1977,1995,2006$ \\
ST & $1956,1957,1967,1968,1972,1982,1983,1984,1991$, & $1948,1952,1953,1973,1976,1978,1985,1987,1995$, \\
& $1997,1999,2007$ & 2002 \\
VD2 & $1954,1956,1957,1964,1972,1974,1980,1981,1982$, & $1948,1949,1952,1953,1959,1961,1976,1977,1978$, \\
& $1991,1992,2005,2006$ & $1986,2001,2002,2003,2009,2010$ \\
Punta Arenas precipitation & $1954,1955,1956,1957,1968,1969,1975,1976,1990$, & $1950,1951,1952,1953,1958,1962,1965,1973,1978$, \\
& $1992,1996,1997,1999,2000$ & $1984,1985,1987,2004,2008$ \\
Punta Arenas temperature & $1950,1951,1977,1983,1984,2002,2004,2007,2008$ & $1954,1955,1960,1960,1964,1965,1967,1968,1969$, \\
& & $1971,1974,1976,1979,1979$ \\
\hline
\end{tabular}


vary between the chronologies, leading to diverse patterns of geopotential height in the composite maps. Nevertheless, these indicate the importance of the areas of Amundsen, Bellingshausen and Ross Seas in addition to the Tropical Pacific and Atlantic representing key sectors modulating the climate leading to extreme growth years and climate anomalies in mid-latitude South America (Montecinos and Aceituno 2003; Kwok and Comiso 2002; Silvestri and Vera 2003, 2009; Pezza et al. 2007; Fogt and Wovrosh 2015). SLP, low SST and air temperature in Amundsen and Bellingshausen Seas are also found in connection to anomalous positive SOI years as early noted by Aceituno (1989) and Grim et al. (2000), which is consistent with our results. Moreover, composite maps of reconstructed palmer drought severity index (Christie et al. 2009) from chronologies between $35^{\circ}$ to $38^{\circ} \mathrm{S}$ indicate wet conditions when high pressure dominated the Amundsen and Bellingshausen and Weddell Seas. Consequently, dry conditions were suggested with enhanced activity of the southeastern Pacific anticyclone, these patterns are in accordance with our findings (Fig. 8b, c, f-h).

\section{Conclusions}

Six newly developed Nothofagus betuloides TRW chronologies from the southern archipelago between the $50^{\circ}$ and $56^{\circ} \mathrm{S}$ were presented and their climate signals analyzed. The chronologies spanned between 202 and 478 years, displaying strong common signals in trees at individual sites, but with less agreement among the sites, reflecting the strong climatic and geographical heterogeneity in the region. The relationships between the tree-ring indices and climate data varied among sites in both time and space, suggesting that other environmental factors, including ecological conditions at the microsite level, can have large impacts on tree growth decreasing the influence of climate parameters on the climate signal at the studied sites. On the other hand, the lack of station data across the region likely hampers the results. In addition, changes in atmospheric and oceanic circulation regimes may also affect site-specific climate responses, and strengthening responses to climate since the 1970s at the sites, suggesting that an intermittent dominant mode of variability may at certain periods override local climatic differences. The correlations with the SAM and SOI indices showed limited impacts of these modes on tree-growth variability. However, the analyses suggested tree growth influences of SLP and SST over the Amundsen, Bellingshausen and Weddell Seas, and teleconnections to the tropical and subtropical Pacific. We showed that tree-ring data from the studied region contain useful climate information, but to make robust climate data, either data from more climate sensitive sites are needed, or other tree-ring proxies should be explored.
Authors contribution statement MF, JCA and HL planned the study and collected the tree-ring data. MF measured the tree-ring data, designed the study, analyzed the data and led the writing of the manuscript. AS was involved in the data analysis. All co-authors contributed to the writing.

Anknowledgements This work could not have been done without the generosity of Adlerbertska forskning Stiftelsen, KVA, Donationsfond granted to MF; AS acknowledges support by the German Research Foundation (DFG, SE 2802/1-1). Finally, we want to thank Achim Bräuning and Ulrich E. Luettge who helped with the editing of this manuscript and for the invaluable comments of two anonymous reviewers.

Funding This work could have not been possible without the funding provided by the Royal Swedish Academy of Sciences, Filosofiska fakulteternas gemensamma donationsnämnd, Adlerbertska fosrkningsstiftelsen and the Geografiska Foreningen. AS is funded by the German Research Foundation (DFG, SE 2802/1-1).

\section{Compliance with ethical standards}

Conflict of interest The authors declare that they have no conflict of interest.

Open Access This article is distributed under the terms of the Creative Commons Attribution 4.0 International License (http://creativeco mmons.org/licenses/by/4.0/), which permits unrestricted use, distribution, and reproduction in any medium, provided you give appropriate credit to the original author(s) and the source, provide a link to the Creative Commons license, and indicate if changes were made.

\section{References}

Abram NJ, Mulvaney R, Vimeux F, Phipps SJ, Turner J, England MH (2014) Evolution of the southern annular mode during the past millennium. Nat Clim Change 4:564-569. https://doi.org/10.1038/ nclimate 2235

Aceituno P (1988) On the functioning of the southern Oscillation in the south American sector. Part I surface climate. Mon Weather Rev 116:505-524

Aceituno P (1989) On the functioning of the southern Oscillation in the South American sector. Part II; upper air circulation. J Clim 2:341-355

Allan RJ, Ansell TJ (2006) A new globally complete monthly historical gridded mean sea level pressure data set (HadSLP2): 1850-2004. J Clim 19:5816-5842

Aravena JC, Luckman BH (2009) Spatio-temporal rainfall patterns in Southern South America Int. J Climatol 29:2106-2120

Aravena JC, Lara A, Wolodarsky-Franke A, Villalba R, Cuq E (2002) Tree-ring growth patterns and temperature reconstruction from Nothofagus pumilio (Fagaceae) forests at the upper tree line of southern Chilean Patagonia. Rev Chil His Nat 75(2):361-376

Boninsegna JA, Keegan J, Jacoby GC, D’Arrigo R, Holmes RL (1989) Dendrochronological studies in Tierra del Fuego, Argentina. Quat South Am Antarct Penins 7:315-326

Boninsegna JA, Argollo J, Aravena JC, Barichivich J, Christie D, Ferrero ME, Lara A, Le Quesne C, Luckman BH, Masiokas M, Morales M, Oliveira JM, Roig F, Srur A, Villalba R (2009) 
Dendroclimatological reconstructions in South America. A review. Palaeogeogr Palaeocl 281:210-228

Büntgen U, Tegel W, Heussner KU, Hofmann J, Kontic R, Kyncl T, Cook ER (2012) Effects of sample size in dendroclimatology. Clim Res 53(3):263-269

Carrasco JF, Casassa G, Rivera A (2002) Meteorological and climatological aspects of the southern Patagonia icefields In: Casassa G, Sepulveda FV, Sinclair RM (eds) The Patagonian ice fields a unique natural laboratory for environmental and climate change studies, Kluwer Academic/Plenum Publisher, New York, 29-41

Christie D, Boninsegna J, Cleaveland MK, Lara A, Le Quesne C, Morales M, Mudelsee M, Stahle DW, Villalba R (2009) Aridity changes in the temperate-Mediterranean transition of the andes since AD 1346 reconstructed from tree-rings. Clim Dyn 36:1505-1521

Cook ER, Peters K (1981) The smoothing spline: a new approach to tandardizing forest interior tree-ring width series for dendroclimatic studies. Tree Ring Bull 41:45-53

Cook ER, Peters K (1997) Calculating unbiased tree-ring indices for the study of climatic and environmental change 7 (3): 361-370

Dätwyler C, Neukm R, Abram N, Gallant A, Grosjean M, JacquesCoper M, Karoly D, Villaba R (2017) Teleconnection stationarity, variability and trends of the southern annular mode (SAM) during the last millennium. Clim Dyn. https://doi.org/10.1007/ s00382-017-4015-0

Fogt R, Wovrosh A (2015) The relative influence of tropical sea surface temperatures radiative forcing on the Amundsen Sea low. J Clim 28:8540-8555

Fogt RL, Perlwitz J, Monaghan AJ, Bromwich DH, Jones JM, Marshall GJ (2009) Historical SAM variability. Part II: twentieth-century variability and trends from reconstructions, observations, and the IPCC AR4 models. J Clim 22:5346-5365

Fritts HC (1976) Tree Rings and Climate. Academic Press, London, 567

Garreaud R, Vuille M, Compagnucci R, Marengo J (2009) Present day South American climate Palaeogeogr. Palaeoclimatol Palaeoecol 281:180-195

Garreaud R, Lopez P, Minvielle M, Rojas M (2013) Large-Scale Control on the Patagonian Climate. J Clim 26:215-230

Gerding V, Thiers O (2002) Caracterización de suelos bajo bosques de Nothofagus betuloides (Mirb) Blume, en Tierra del Fuego, Chile. Rev. Chil His Nat. 75: 819-833

Gong D, Wang S (1999) Definition of Antarctic Oscillation Index. Geophys Res Lett 26:459-462

González-Reyes A, Aravena JC, Muñoz A, Soto_Rogel P, AguileraBetti I, Toledo-Guerrero I (2017) Variabilidad de la precipitación en la ciudad de Punta Arenas, Chile, desde principios del siglo XX. An Inst Patagon (Chile) 45(1):31-44

Grim A, Barros V, Doyle M (2000) Climate variability in southern South America with el Niño and La Niña. Events J Clim 13:35-58

Holmes RL (1983) Computer-assisted quality control in tree-ring dating and measurement. Tree Ring Bull 43:69-78

Jones J (2012) Tree rings and storm tracks. Nat Geosi 5:764-765

Kalnay E, Kanamitsu M, Kistler R, Collins W, Deaven D, Gandin L, Iredell M, Saha S, White G, Woollen J, Zhu Y, Leetmaa A, Reynolds R, Chelliah M, Ebisuzaki W, Higgins W, Janowiak J, Mo KC, Ropelewski C, Wang Jenne R, Joseph D (1996) The NCEP/NCAR 40-year reanalysis project. Bull Am Meteor Soc 77:437-470, 1996

Kwok R, Comiso JC (2002) Southern Ocean climate and sea ice anomalies associated with the Southern Oscillation. J Clim 15:487-501

Lara A, Bahamondez A, González-Reyes A, Muñoz A, Cuq E, RuizGómez C (2015) Reconstructing streamflow variation of the Baker River from tree-rings in Northern Patagonia since 1765. J Hydrol 529:511-523

Le Quesne C, Stahle DH, Cleaveland MK, Therrell M, Aravena JC, Barichivich J (2006) Ancient Austrocedrus tree-ring chronologies used to reconstruct central Chile precipitation variability from A.D. 1200 to 2000. J Clim 19:5731-5744

Lee T, Hobbs W, Willis J, Halkides D, Fukumori I, Armstrong E, Hayashi A, Liu T, Patzert W, Wand O (2010) Record warming in the South Pacific and western Antarctica associated with the strong central-Pacific El Niño in 2009-10. Geophys Res Lett 37:L19704. https://doi.org/10.1029/2010GL044865

Linderholm HW, Chen D (2005) Central Scandinavian winter precipitation variability during the past five centuries reconstructed from Pinus sylvestris tree rings. Boreas 34:43-52 (Oslo. ISSN 0300-9483)

Linderholm HW, Zhang P, Gunnarson BE, Björklund J, Farahat E, Fuentes M, Rocha E, Salo R, Seftigen K, Stridbeck P, Liu Y(2015) Growth dynamics of tree line and lake shore Scots pine (Pinus sylvestris $\mathrm{L}$ ) in the Central Scandinavian Mountains during the medieval climate anomaly and the early little ice age. Front Ecol Evol 2:20. https://doi.org/10.3389/fevo.2014.00020

Llancabure JJ (2011) Relaciones entre el crecimiento de Nothofagus betuloides y el clima local y de gran escala en bosques subantárticos de la Isla Navarino. Tesis Ingeniero Forestal, Facultad de Ciencias Forestales y Recursos Naturales, Universidad Austral de Chile, Valdivia, Chile

Logan JA, Regniere J, Powell JA (2003) Assessing the impacts of global warming on forest pest dynamics. Front Ecol Environ $1: 130-137$

Marshall GJ (2003) Trends in the southern annular mode from observations and reanalysis. J Clim 16:4134-4143

Melvin T, Briffa K (2008) A "signal-free" approach to dendroclimatic standardization. Dendrochronologia. https://doi. org/10.1016/j.dendro.2007.12.001

Miller A (1976) The Climate of Chile. In: Schwerdtfeger W (ed) World survey of climatology. Climates of Central and South America. Elsevier, Amsterdam, pp 113-131

Montecinos A, Aceituno P (2003) Seasonality of the ENSO related rainfall variability in central Chile and associated circulation anomalies. J Clim 16:281-296

Moreno P, Vilanova I, Villa-Martínez R, Garreaud R, Rojas M, De Pol-Holz R (2014) Sourthern annular mode-like changes in southwestern Patagonia at centennial timescales over the last three millennia. Nat Commun. https://doi.org/10.1038/ncomm s5375

Paritsis J, Veblen TT (2011) Dendroecological analysis of defoliator outbreaks on Nothofagus pumilio and their relation to climate variability in the Patagonian Andes. Global Chang Biol 17:239-253

Pezza A, Simmonds I, Renwick J (2007) Southern hemisphere cyclones and anticyclones: Recent trends and links with decadal variability in the Pacific Ocean Int. J Climatol 27:1403-1419

Pisano E (1977) Fitogeografía de Fuego-Patagonia Chilena. I. Comunidades vegetales entre las latitudes $52^{\circ}$ y $56^{\circ} \mathrm{S}$ Anales Instituto Patagonia (Chile), 8 pp 121-250

Quintana JM, Aceituno P (2012) Changes in the rainfall regime along the extratropical west coast of South America (Chile): $30-43^{\circ} \mathrm{S}$. Atmósfera 25(1):1-22

Rayner NA, Parker DE, Horton EB, Folland CK, Alexander LV, Rowell DP, Kent EC, Kaplan A (2003) Global analyses of sea surface temperature, sea ice, and night marine air temperature since the late nineteenth century. J Geophys Res 108(D14): 4407. https:// doi.org/10.1029/2002JD002670

Ropelewski CF, Jones PD (1987) An extension of the Tahiti-Darwin Southern Oscillation Index. Mon Weather Rev 115:2161-2165

Schneider C, Gies D (2004) Effects of El Nino-Southern oscillation on southernmost South America precipitation at $53^{\circ} \mathrm{S}$ revealed from NCEP-NCAR reanalysis and weather station data. Int J Climatol 24:1057-1076 
Schneider C, Glaser M, Kilian R, Santana A, Butorovic N, Cassasa G (2003) Weather observations across the southern Andes at $53^{\circ} \mathrm{S}$. Phys Geogr 24(2):97-119

Silvestri G. Vera C (2003) Antarctic oscillation signal on precipitation anomalies over southeastern South America. Geophys Res Lett 30:2115. https://doi.org/10.1029/2003GL018277

Silvestri G, Vera C (2009) Nonstationary impacts of the southern annular mode on southern hemisphere climate. J Clim 22:6142-6148

Soto-Rogel P, Aravena JC (2017) Potencial dendroclimático de Nothofagus betuloides en la Cordillera de Darwin, Tierra del Fuego. Chile. Bosque 38(1):155-168

Stine AR, Huybers P (2014) Artic tree rings as recorders of variations in light availability. Nature 5:3836. https://doi.org/10.1038/ ncomms 4836

Stokes M, Smiley T (1968) An introduction to tree-ring dating. University of Chicago Press, Chicago, pp 73

Tranquil in i. W (1979) Physiohigical Ecology of the Alpine Timherline. Tree E.xislenee a! High Altitudes with.Special References to the European Alps, Ecological Studies, 31. Springer, Berlin

Trouet V, Van Oldenborgh GJ (2013) KNMI Climate explorer: a web based research tool for high resolution paleoclimatology. Tree Ring Res. 69(1): 3-13

Turner J, Hosking JS, Bracegirdle T, Phillips T, Marshall G (2016) Variability and trends in the southern Hemisphere high latitude, quasi-stationary planetary waves. Int J Climatol. https://doi. org/10.1002/joc. 4848

Veblen TT, Donoso C, Kitsberger T, Rebertus AJ (1996b) Ecology southern Chilean and Argentinian Nothofagus forests In: Veblen TT, Hill RS, Read J (eds) The ecology and biogeography of Nothofagus forests Yale University, Michigan, pp 293-253

Veblen TT, Kitzberger t, Burns BR, Rebertus Aj 1996a Perturbaciones y dinámica de regeneración den bosques andinos del sur de Chile y Argentina. In: Armesto JJ, Villagrán C, Arroyo MTK (eds) Ecología de los bosques nativos de Chile, 469. Editorial Universitaria, Santiago, pp 169-198
Villalba R (2007) Tree-ring evidence for tropical-extratropical influences on climate variability along the Andes in South America. PAGES Newsl 15:23-25

Villalba R, Cook ER, D' Arrigo RD, Jacoby GC, Jones PD (1997) Sea-level pressure variability around Antarctica since A.D. 1750 inferred from subantarctic tree-ring records. Clim Dyn 13:375-390

Villalba R, D’Arrigo R, Cook E, Jakoby G, Wiles G (2001) Decadalscale climatic variability along the extratropical western coast of the Americas: evidence from tree-ring records. In: Markgraf V (ed) Interhemispheric climate linkages. Academic Press, Institute of Arctic and Alpine Research University of Colorado Boulder, Colorado, USA, p 454 (ISBN: 978-0-12-472670-3)

Villalba R, Lara A, Boninsegna JA, Masiokas M, Delgado S, Aravena JC, Roig FA, Schmelter A, Wolodarsky A, Ripalta A (2003) Large-scale temperature changes across the Southern Andes: 20th-century variations in the context of the past 400 years. Clim Chang 59:177-232

Villalba R, Lara A, Masiokas MH, Urrutia R, Luckman BH, Marshall G, Mundo IA, Christie DA, Cook ER, Neukom R, Allen K, Fenwick P, Boninsegna JA, Srur AM, Morales MS, Araneo D, Palmer JG, Cuq E, Aravena JC, Holz A, LeQuesne C (2012) Unusual southern Hemisphere tree growth patterns induced by changes in the southern annular mode. Nature Geosci 5:793-798

Wigley TM, Briffa KR, Jones PD (1984) On the average value of correlated time series, with applications in dendroclimatology and hydrometeorology. J Clim Appl Meteorol 23:201-213

Yamaguchi D (1981) A simple method for cross-dating increment cores from living trees. Can J For Res 21(3):414-416 1991

Publisher's Note Springer Nature remains neutral with regard to jurisdictional claims in published maps and institutional affiliations. 